\title{
Bis-Pyrene Photo-Switch Open- and Closed-Form Differently Bind to ds-DNA, ds-RNA and Serum Albumin and Reveal Light-Induced Bioactivity
}

\author{
Iva Orehovec ${ }^{1}$, Marija Matković ${ }^{1}$, Isabela Pehar ${ }^{2} \mathbb{D}$, Dragomira Majhen ${ }^{2} \mathbb{D}$ and Ivo Piantanida ${ }^{1, * \mathbb{D}}$ \\ 1 Division of Organic Chemistry and Biochemistry, Ruđer Bošković Institute, Bijenička Cesta 54, \\ 10000 Zagreb, Croatia; Iva.Orehovec@irb.hr (I.O.); Marija.Matkovic@irb.hr (M.M.) \\ 2 Division of Molecular Biology, Ruđer Bošković Institute, Bijenička Cesta 54, 10000 Zagreb, Croatia; \\ Isabela.Pehar@irb.hr (I.P.); Dragomira.Majhen@irb.hr (D.M.) \\ * Correspondence: pianta@irb.hr; Tel.: +385-1-4571-326
}

check for updates

Citation: Orehovec, I.; Matković, M.; Pehar, I.; Majhen, D.; Piantanida, I. Bis-Pyrene Photo-Switch Open- and Closed-Form Differently Bind to ds-DNA, ds-RNA and Serum Albumin and Reveal Light-Induced Bioactivity. Int. J. Mol. Sci. 2021, 22, 4916. https://doi.org/10.3390/ ijms22094916

Academic Editor: Luca Agnelli

Received: 7 April 2021

Accepted: 30 April 2021

Published: 6 May 2021

Publisher's Note: MDPI stays neutra with regard to jurisdictional claims in published maps and institutional affiliations.

Copyright: (c) 2021 by the authors. Licensee MDPI, Basel, Switzerland. This article is an open access article distributed under the terms and conditions of the Creative Commons Attribution (CC BY) license (https:// creativecommons.org/licenses/by/ $4.0 /)$

\begin{abstract}
Newly designed and synthesized diarylethene (DAE) derivatives with aliphatic amine sidearms and one with two pyrenes, revealed excellent photo-switching property of central DAE core in $\mathrm{MeOH}$ and water. The only exception was bis-pyrene analogue, its DAE core very readily photochemically closed, but reversible opening completely hampered by aromatic stacking interaction of pyrene(s) with cyclic DAE. In this process, pyrene fluorescence showed to be a reliable monitoring method, an open form characterized by strong emission at $480 \mathrm{~nm}$ (typical for pyrene-aggregate), while closed form emitted weakly at $400 \mathrm{~nm}$ (typical for pyrene-DAE quenching). Only open DAEbis-pyrene form interacted measurably with ds-DNA/RNA by flexible insertion in polynucleotide grooves, while self-stacked closed form did not bind to DNA/RNA. For the same steric reasons, flexible open DAE-bis-pyrene form was bound to at least three different binding sites at bovine serum albumin (BSA), while rigid, self-stacked closed form interacted dominantly with only one BSA site. Preliminary screening of antiproliferative activity against human lung carcinoma cell line A549 revealed that all DAE-derivatives are non-toxic. However, bis-pyrene analogue efficiently entered cells and located in the cytoplasm, whereby irradiation by light (315-400 nm) resulted in a strong, photo-induced cytotoxic effect, typical for pyrene-related singlet oxygen species production.
\end{abstract}

Keywords: photo-switch; diarylethene; pyrene; DNA; RNA binding; BSA binding; cell uptake; cytotoxicity

\section{Introduction}

Synthetic small molecules targeting DNA, RNA or proteins by non-covalent interactions are of utmost scientific and biomedical interest [1], among which dyes attract attention not only because spectrophotometric probing is essential in the biomedical research [2,3], but also due to theranostic applications by combining, e.g., fluorimetric probing with biological (therapeutic) activity [4,5].

The biological action of small molecules controlled by outer stimuli has become of high interest rather recently; for instance, pH-controlled DNA-targeting systems [6-8], or photo-induced formation of bioactive and fluorescent molecules [9,10].

Particularly, reversible photo-control of biological systems by molecular photo-switches attracted considerable attention [11,12]. In respect to DNA-controlled non-covalent binders, the pioneering work of Feringa et al. showed how small molecule non-covalently bound to ds-DNA can upon photo-induced reversible chemical transformation influence DNA structure [13]. Similarly, it was shown that DNA helicity can be somewhat changed by photoswitchable small molecules [14]. Lately, significant progress was made by Ihmels et al., demonstrating a wide range of heterocyclic systems, which can be finely tuned [15-18]. In addition, very recently new photo-switchable non-covalently interacting optoepigenetic 
tools for conditional modulation of nucleosomal DNA accessibility were reported [19]. Likewise, photo-dependent melting of unmodified DNA using a photosensitive intercalator as a new and generic tool for photo-reversible assembly of DNA nanostructures has been described [20]. Further, photo-controlled capture and release of DNA and proteins were demonstrated by host-guest constructs [21]. Low molecular weight photo-switch incorporated into DNA structure was able to control two single-stranded DNAs to reversibly intertwine into ds-DNA [22].

Particularly, diarylethenes (DAE) drew our attention due to the high conversion rate (mostly close to $100 \%$ ), at variance to lower conversion rates of other photo-switches (e.g., diaza mostly being about $70-80 \%$, although some analogues showed promising increase [23]). In addition, some diarylethene derivatives showed highly fluorescent "closed" forms [24], very promising property for the applications like super-resolution microscopy [25].

Inspired by considerable advancement in photo-switch recognition of bio-related systems, we aimed for the development of a new, fluorescent, low molecular weight conjugate able to non-covalently interact with DNA, RNA and/or protein, whereby recognition properties could be controlled by a photo-switchable process. The photo-induced bioactivity of the novel small molecule would be screened on cell lines.

Starting from DAE-derivative targeting ds-DNAs studied by Feringa [13], and with the aim to increase the structural impact of the cyclisation-decyclisation process of DAE, we decided to shorten the linker between DAE and aliphatic amine by omitting benzene rings used by Feringa [13] (Scheme 1, DAE- $\mathrm{NH}_{2}$ ). Further, we introduced pyrenes at the termini of both arms (Scheme 1, DAE-NH-Py), to allow sensitive monitoring of the photo-switching process by fluorescence. Namely, pyrene fluorescence is very sensitive to the microenvironment [2] and also can form excimers characterized by very specific emission $[2,26]$. Therefore, pyrenes were intensively used for various probing of DNA/RNA/proteins [2,26,27], as well as theragnostic agents [5,28]. Moreover, some pyrene derivatives were applicable in photodynamic therapy (PDT) under two-photon absorption (PTA) conditions [29]. In this work pyrenes in DAE-NH-Py are expected to sense fine differences within DNA/RNA/protein binding site and also contribute to the binding by hydrophobic and aromatic stacking interactions. Furthermore, pyrene(s) can also stack by aromatic interactions on the "closed", planar form of DAE, but not to "open", non-planar form of DAE, in this way directly controlling the small molecule geometry and flexibility.

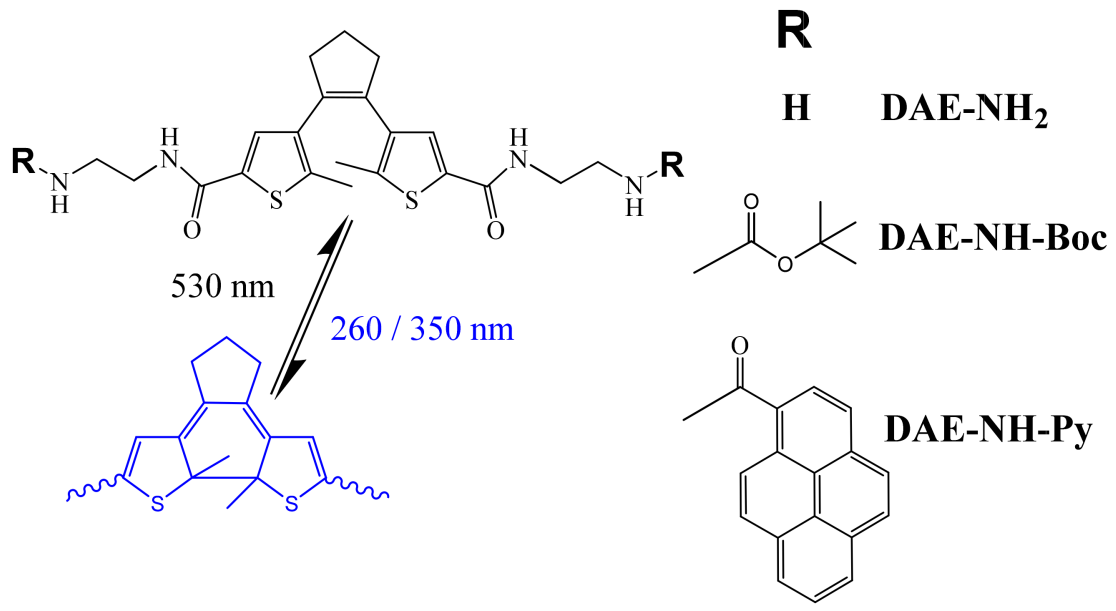

Scheme 1. Studied diarylethene (DAE) compounds. Note reversible photo-switching; irradiation by UV light results in cyclization (BLUE), which can be reversed by irradiation in the visible range $(530 \mathrm{~nm})$.

As targeted biomacromolecules, we have chosen ds-DNA/RNA of various secondary structure (Table S1, Supplementary Materials), thus differing in properties of binding sites 
(minor or major grooves and eventually intercalation): namely, we previously showed interesting applications of pyrene fluorophore by relying on its interactions with the DNA or RNA grooves [30] or combined with switch on and off of pyrene excimer [6-8]. In addition, since some pyrene analogues tended to prefer proteins over ds-DNA [31], we studied interactions of new compounds with the representative protein, i.e., bovine serum albumin (BSA), the most abundant protein in blood plasma responsible for the transport of many small molecules [32,33], which is characterized by up to eight different binding sites [34].

For comparison reasons we also studied analogue with Boc-protected amino groups (Scheme 1, DAE-NH-Boc), whereby Boc-group may be considered similarly hydrophobic as pyrene, but void of aromaticity and being globular instead of planar.

In this work, we showed by a set of spectrophotometric methods (UV/vis, fluorescence, circular dichroism and DNA/RNA thermal denaturation experiments) that photo-induced switching (Scheme 1) very efficiently works for new compounds under well-defined conditions. In addition, closed and open form of bis-pyrene DAE-NH-Py very differently interacted with both, DNA/RNA and protein (BSA). Preliminary screening on human tumour cell line showed efficient cellular uptake of DAE-NH-Py, accompanied by negligible toxicity in dark, but showed increased biological activity under light excitation of pyrenes.

\section{Results}

\subsection{Synthesis}

The core diarylethene switch $S$ was prepared in four steps according to the procedure already described in the literature [35] with some modifications in the synthetic process (Supplementary Materials, Scheme S1). Further, we extended core-switch DAE with flexible side-arms N-Boc-ethylenediamine (DAE-NH-Boc, Scheme 2), by application of mild coupling method well known in peptide chemistry [36]. Deprotection by common procedure [37] resulted in diamine derivative DAE- $\mathrm{NH}_{2}$ (Scheme 2).

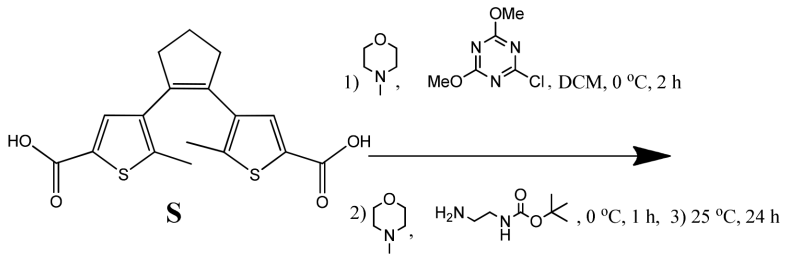

2) 1)<smiles>CCCNC(=O)c1ccc(C(=O)NCCNC(=O)c2ccc3ccc4cccc5ccc2c3c45)c(C(=O)NCCNC(=O)c2ccc3ccc4cccc5ccc2c3c45)c1</smiles><smiles>Cc1sc(C(=O)NCCNC(=O)c2cc(C3=C(c4cc(C(=O)NCCNC(=O)OC(C)(C)C)sc4C)CCC3)c(C)s2)cc1C(=O)NCC(C)(C)C</smiles><smiles>Cc1sc(C(=O)NCCN)cc1C1=C(c2cc(C(=O)NCC[NH3+])sc2C)CCC1</smiles>

Scheme 2. Synthesis of referent compounds DAE-NH-Boc and DAE-NH $\mathrm{N}_{2}$ and targeted pyrene derivative DAE-NH-Py.

Attempt to prepare desired pyrene derivative DAE-NH-Py by simple coupling of DAE- $\mathrm{NH}_{2}$ with 1-aminopyrene was unsuccessful due to complete degradation of the product during purification. Therefore, we opted for a parallel route, preparing DAE-NHPy by direct reaction of $S$ with separately prepared N-(2-aminoethyl)pyrene-1-carboxamide 
(Supplementary Materials; Scheme S4), whereby the final DAE-NH-Py was obtained in a rather low yield due to losses during purification (Scheme 2).

\subsection{Spectrophotometric Characterisation}

Compound DAE-NH-Boc was dissolved in $\mathrm{MeOH}$ at $10^{-3} \mathrm{~mol} \mathrm{dm}^{-3}$, DAE- $\mathrm{NH}_{2}$ was dissolved in $\mathrm{mQ} \mathrm{H}_{2} \mathrm{O}$ at $10^{-3} \mathrm{~mol} \mathrm{dm}{ }^{-3}$ and DAE-NH-Py was dissolved in DMSO at $10^{-3} \mathrm{~mol} \mathrm{dm}{ }^{-3}$. These stock solutions were stored at $+4{ }^{\circ} \mathrm{C}$ and daily working aliquots kept at $+25^{\circ} \mathrm{C}$. The experiments were performed in buffer solution (sodium cacodylate buffer, $I=50 \mathrm{mM}, \mathrm{pH}=7.0$ ) and in $\mathrm{MeOH}$.

DAE-NH-Boc, DAE-NH $\mathrm{N}_{2}$ and DAE-NH-Py absorbance in aqueous buffered solutions or $\mathrm{MeOH}$ solutions of compounds were proportional to their concentration up to $10 \mu \mathrm{M}$ (Supplementary Materials, Figures S1-S8), corresponding UV/Vis data given in Table 1.

Table 1. Electronic absorption data of DAE-NH-Boc, DAE-NH $\mathrm{N}_{2}$ and DAE-NH-Py (open and closed form).

\begin{tabular}{|c|c|c|c|c|}
\hline Compound & $\lambda(\mathrm{MeOH}) / \mathrm{nm}$ & $\varepsilon(\mathrm{MeOH}) / \mathrm{mmol}^{-1} \mathrm{~cm}^{2}$ & $\lambda($ Buffer$) / n m$ & $\varepsilon$ (Buffer) $/ \mathrm{mmol}^{-1} \mathrm{~cm}^{2}$ \\
\hline DAE-NH-Boc & 261 & 95,211 & 266 & 22,423 \\
\hline${\mathrm{DAE}-\mathrm{NH}_{2}}_{2}$ & - & - & 264 & 17,588 \\
\hline DAE-NH-Py (open) & $\begin{array}{l}275 \\
341\end{array}$ & $\begin{array}{l}43,206 \\
27,724\end{array}$ & $\begin{array}{l}280 \\
348\end{array}$ & $\begin{array}{l}29,577 \\
17,637\end{array}$ \\
\hline a DAE-NH-Py (closed) & 275 & 46,910 & $\begin{array}{l}280 \\
347 \\
530\end{array}$ & $\begin{array}{c}36,254 \\
26,792 \\
4252\end{array}$ \\
\hline
\end{tabular}

a Prepared by photochemical reaction in $\mathrm{MeOH}$ as described under Section 2.3.1, $\mathrm{MeOH}$ subsequently evaporated and "DAE-NH-Py closed form" re-dissolved in buffer ( $<1 \% \mathrm{DMSO})$.

Comparison of UV/Vis spectra of pyrene analogue DAE-NH-Py collected in aqueous solution and $\mathrm{MeOH}$ showed distinct differences (Figure 1a). The DAE-NH-Py spectrum in $\mathrm{MeOH}$ showed sharp and well-defined maxima, very similar to referent pyrene-carboxylic acid (Figure 1a, Py-COOH) and typical of free pyrene moiety [2]. Dissimilarly, DAE-NH-Py aqueous solution UV/Vis spectrum showed strong hypochromic (32\%) and bathochromic $(+\Delta \lambda=12 \mathrm{~nm})$ effect in respect to $\mathrm{MeOH}$-solution and referent $\mathrm{Py}-\mathrm{COOH}$, which can be attributed to the intramolecular stacking interactions of aromatic subunits [2,26].

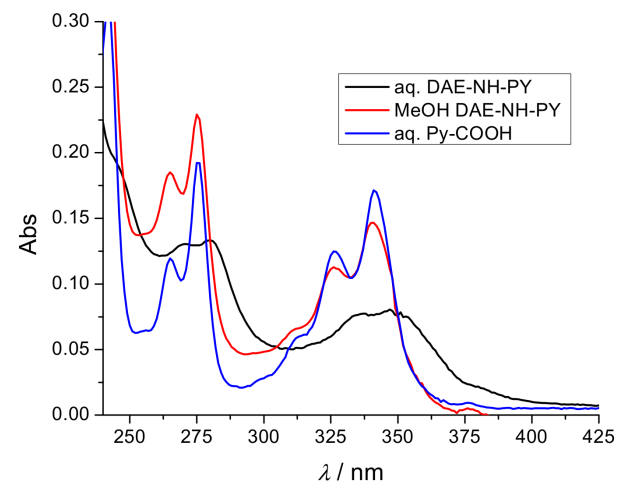

(a)

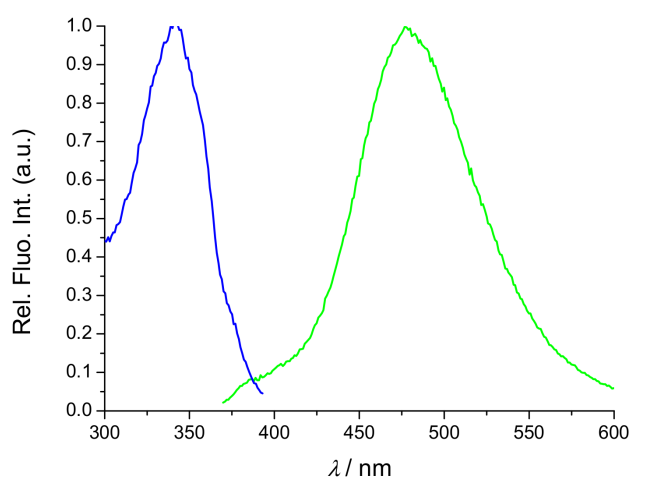

(b)

Figure 1. (a) UV/Vis spectra of DAE-NH-Py $\left(c=5.0 \times 10^{-6} \mathrm{M}\right)$ in $\mathrm{MeOH}(-)$ and in aqueous buffer $(-)$ at $\mathrm{pH} 7.0$, sodium cacodylate buffer, $I=50 \mathrm{mM}(1 \% \mathrm{DMSO})$, compared to referent 1-pyrenecarboxylic acid (-, starting material) in at $\mathrm{pH} 7.0$, sodium cacodylate buffer, $I=50 \mathrm{mM}$. (b) Emission $\left(-, \lambda_{\mathrm{exc}}=348 \mathrm{~nm}\right)$ and excitation $\left(-, \lambda_{\mathrm{em}}=478 \mathrm{~nm}\right)$ spectrum of DAE-NH-Py $\left(c=1.0 \times 10^{-6} \mathrm{M}\right)$ at pH 7.0, sodium cacodylate buffer, $I=50 \mathrm{mM}$ (1\% DMSO). 
The pyrene analogue also exhibited fluorescence emission with a maximum at $478 \mathrm{~nm}$ (Figure 1b), whereas the corresponding excitation spectrum (Figure 1b) agreed well with UV/Vis spectrum (Figure 1a), confirming the involvement of the same chromophore (pyrene). Since the emission of pyrene in water is characterized by three sharp emission maxima around $400 \mathrm{~nm}$ [2], here observed strong bathochromic shift of emission is characteristic for pyrene excimer $(500 \mathrm{~nm})$ [26] or eventually aromatically stacked pyrene with some other aromatic moiety, e.g., DAE.

\subsection{Photochemistry}

Diarylethene (DAE) reversible photochemistry (Scheme 1) relies on photo-cyclisation of DAE upon irradiation by UV light, whereby formation of cyclic product is monitored by the appearance of new absorption maximum at about $530 \mathrm{~nm}$. The irradiation of cyclic DAE by visible light (around $530 \mathrm{~nm}$ ) causes ring-opening, again monitored by decrease and eventually the disappearance of 530 absorption maximum.

For better quantification of applied light, we used a photoreactor (Luzchem, LZCICH2), equipped with four side-mounted LZC-UVB lamps (in total $32 \mathrm{~W}, 254-315 \mathrm{~nm}$ ) for cyclisation reaction and four side-mounted LZC-420 lamps (in total $32 \mathrm{~W}$, range $400-700 \mathrm{~nm}$ ) for de-cyclisation reaction. Solutions were irradiated in standard $1 \mathrm{~cm}$ pathlength quartz cuvettes, which allowed instant measurement of UV/Vis or fluorescence spectra.

\subsubsection{Photo-Controlled Switching of DAE-NH-Boc, DAE-NH $\mathrm{N}_{2}$ and DAE-NH-Py}

All compounds showed excellent solubility in $\mathrm{MeOH}$, which allowed the concentrationdependent study of the photo-cyclisation process upon irradiation with UV light and monitoring the appearance of $\lambda_{\max }=527 \mathrm{~nm}$, specific for cyclic product. At concentrations $\mathrm{c}<0.1 \mathrm{mM}$ cyclisation of all compounds was completed within 12-50 s (Figure 2, Supplementary Materials Figures S9-S17); however, at $c=1 \mathrm{mM}$ cyclisation was significantly slower (up to two orders of magnitude) and at $c=10 \mathrm{mM}$ cyclisation was completely hampered.

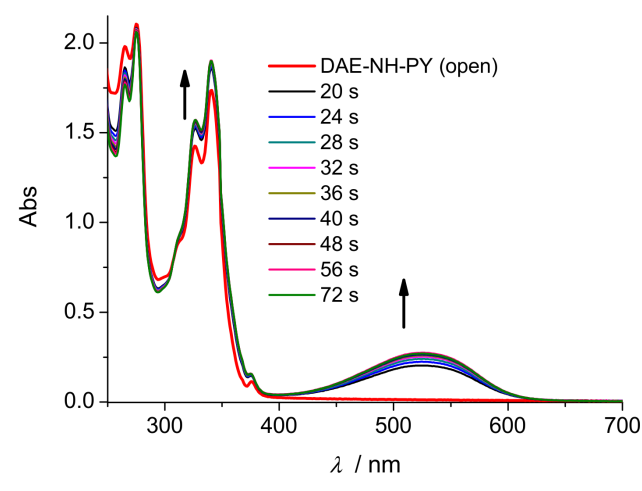

(a)

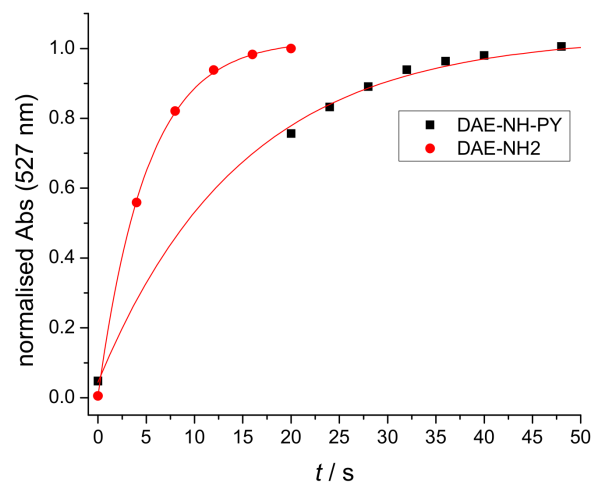

(b)

Figure 2. (a) Changes in UV/Vis spectra of DAE-NH-Py $\left(c=1.0 \times 10^{-4} \mathrm{M}\right)$ during $32 \mathrm{~W}$ lamp, $254-315 \mathrm{~nm}$ range irradiation $\left(t_{\text {tot }}=72.00 \mathrm{~s}\right)$ in $\mathrm{MeOH}(4.3 \%$ DMSO); (b) Normalized Abs changes for DAE-NH-Py and DAE- $\mathrm{NH}_{2}$ at $\lambda=527 \mathrm{~nm}$ as a function of irradiation time.

Such concentration-dependent effect can be attributed to two different causes: (a) due to large $\varepsilon$ values in UV spectra, at high $c$ (compound) $>1 \mathrm{mM}$ the only fraction of photons reaches reactive species, reaction eventually at $10 \mathrm{mM}$ even reaching zero-order kinetics [38] (b) aggregation of aromatic compounds, which by intermolecular non-covalent interactions inhibited photo-induced cyclisation. Latter was additionally supported by a detailed comparison of cyclisation kinetics of DAE-NH-Py and DAE-NH $\mathrm{N}_{2}$ (Figure $2 b$ ), whereby former bis-pyrene analogue photo-conversion was slower, suggesting that important impact of aggregation-prone pyrene units on the photo-cyclisation process. 
The photo-cyclisation process upon irradiation with UV light also worked in aqueous solutions, whereby systematic variation of $\mathrm{MeOH} /$ water ratio did not influence the kinetics of reaction (Supplementary Materials, Figure S18).

Comparison of open and closed from of DAE-NH-Py UV/Vis spectra (Figure 2a) revealed several differences; one was the appearance of the band at $\lambda=527 \mathrm{~nm}$ specific for the closed form, but also systematic absorbance increase within 300-350 nm range is observed, attributed to the change of pyrene chromophore caused by cyclisation of DAE core.

Particularly interesting was the change of DAE-NH-Py fluorescence upon photocyclisation (Figure 3). Starting spectrum of open DAE-NH-Py (characterized by emission at $480 \mathrm{~nm}$, typical for pyrene excimer or aggregate [26] within seconds of UV irradiation strongly hypsochromically shifted $(-\Delta \lambda=80 \mathrm{~nm})$ and decreased in intensity 20 -fold. The emission spectrum of closed DAE-NH-Py resembled very closely to the emission of a single pyrene chromophore, strongly quenched by aromatic interaction with some other aryl moiety [2,26] - likely intramolecularly stacked with closed DAE form. The UV irradiation and subsequent DAE closure did not affect significantly the excitation spectrum of pyrene, proving that pyrene did not undergo any photochemical change.

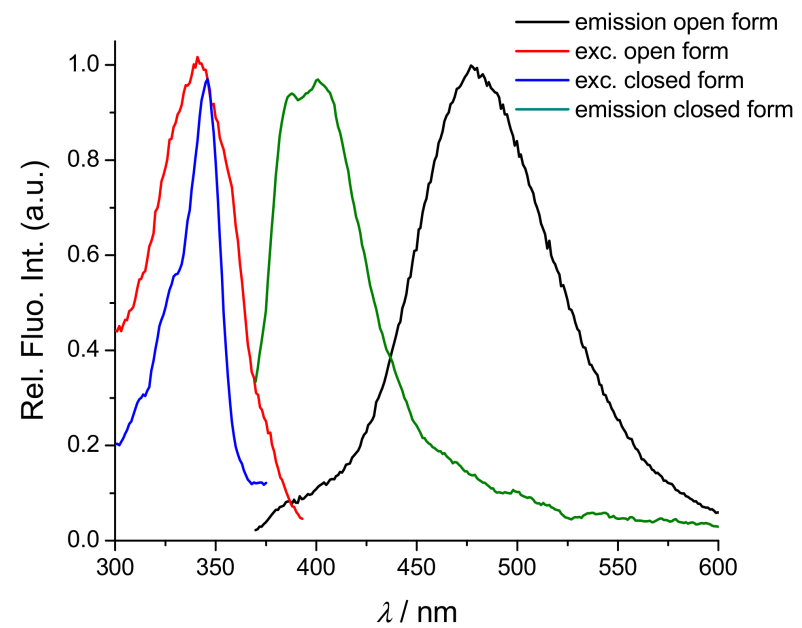

Figure 3. Normalized fluorescence spectra of DAE-NH-Py $\left(c=1.0 \times 10^{-6} \mathrm{M}\right)$ at $\mathrm{pH} 7.0$, sodium cacodylate buffer, $I=0.05 \mathrm{M}\left(1 \%\right.$ DMSO): open DAE-NH-Py: Emission $\left(-, \lambda_{\text {exc }}=348 \mathrm{~nm}\right)$ and excitation $\left(-, \lambda_{\mathrm{em}}=478 \mathrm{~nm}\right)$ and closed DAE-NH-Py: Emission (spectrum multiplied by 20; -, $\left.\lambda_{\text {exc }}=348 \mathrm{~nm}\right)$ and excitation $\left(-, \lambda_{\text {em }}=400 \mathrm{~nm}\right)$ spectrum.

Once prepared, the cyclic (closed) form of DAE- $\mathrm{NH}_{2}$ can be submitted to the reverse process by irradiation with visible light, such de-cyclisation process again monitored at $\lambda_{\max }=527 \mathrm{~nm}$ (Figure $4 \mathrm{~b}$ ). Due to the lower energy of light implemented at longer wavelengths, complete de-cyclisation took about 60-150 min, again independent on a $\mathrm{MeOH} /$ water ratio.

Further, we tested the conversion efficiency of the cyclization-decyclization process in repetitive cycles (Figure 5). The conversion rate decreased with a number of cycles similarly as noted for close analogue of DAE- $\mathrm{NH}_{2}$ in corresponding spectrophotometric experiments [13].

Study in the aqueous environment (water and buffer $\mathrm{pH} 7$ system) revealed that, at variance to efficient de-cyclisation of referent DAE- $\mathrm{NH}_{2}$ (Figure 4) and also efficient de-cyclisation of hydrophobic DAE-NH-Boc (Supplementary Materials, Figure S13 right), a de-cyclisation process of bis-pyrene DAE-NH-Py was almost completely hampered (Supplementary Materials, Figure S17). This can be correlated to slower kinetics of pyreneanalogue in $\mathrm{MeOH}$ (Figure 2, right), which in water progressed to complete blocking of DAE-ring opening, likely due to intensive inter- or intra-molecular interactions of pyrene subunits with DAE-core in cyclic form. 


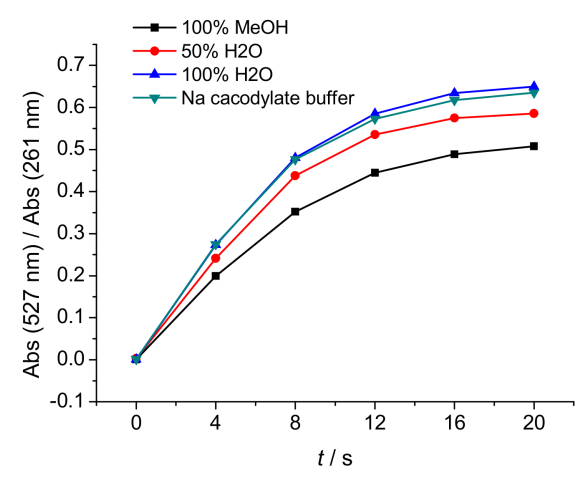

(a)

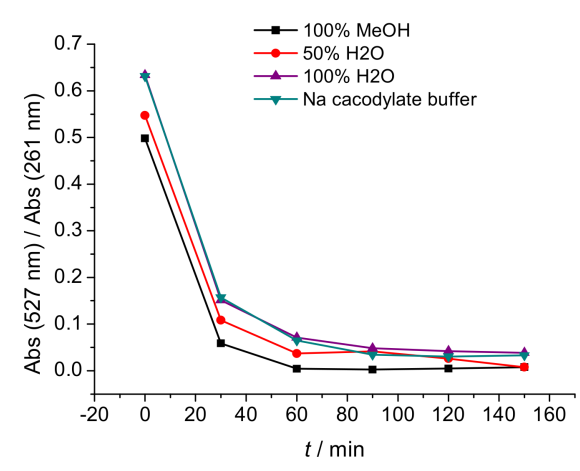

(b)

Figure 4. Measurements of $\mathrm{DAE}_{-} \mathrm{NH}_{2}\left(c=1.0 \times 10^{-4} \mathrm{M}\right)$ at $\mathrm{MeOH}, 50 \% \mathrm{H}_{2} \mathrm{O}$ in $\mathrm{MeOH}, \mathrm{H}_{2} \mathrm{O}$ and Na cacodylate buffer $(\mathrm{pH}=7.0, \mathrm{I}=0.05 \mathrm{M})$ showing $\mathrm{A}_{527} / \mathrm{A}_{261}$ ratios during (a) irradiation with $64 \mathrm{~W}$, range $254-315 \mathrm{~nm}$ lamps, as a function of irradiation time $\left(t_{\text {tot }}=20.00 \mathrm{~s}\right),(\mathbf{b})$ irradiation with $64 \mathrm{~W}$, range $400-700 \mathrm{~nm}$ lamps, as a function of irradiation time $\left(t_{\text {tot }}=150.00 \mathrm{~min}\right)$.

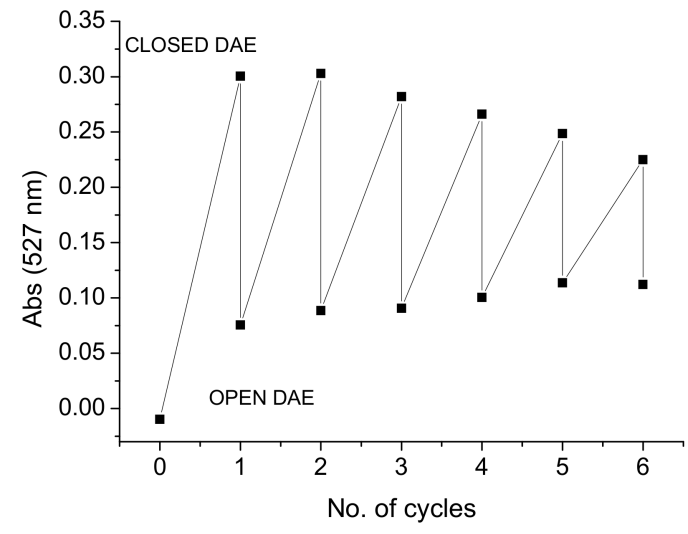

Figure 5. Changes at $\lambda=527 \mathrm{~nm}$ (specific for cyclic DAE form) during 6 repetitive "open-close" irradiations of DAE-NH-Py $\left(c=1.0 \times 10^{-4} \mathrm{M}\right)$, for cyclisation $32 \mathrm{~W}$, range 254-315 nm lamps; for de-cyclisation $32 \mathrm{~W}$, range 400-700 nm lamps, done in $\mathrm{MeOH} / 4.3 \%$ DMSO. Note the decrease in conversion rate in both closed DAE and open DAE form, proportional to the number of cycles.

\subsection{Interactions with $D N A / R N A$}

In all experiments, stock solutions of acyclic and cyclic forms of DAE- $\mathrm{NH}_{2}$ and DAE$\mathrm{NH}-\mathrm{Py}$ were prepared in $\mathrm{mM}$ concentration and then further diluted in buffer $\mathrm{pH} 7$ before the experiment.

\subsubsection{Thermal Denaturation of ds-DNA/RNA}

Non-covalent binding of small molecules to ds-polynucleotides usually increases the thermal stability of the ds-helices, thus resulting in an increased $T_{m}$ value and this increase $\left(\Delta \mathrm{T}_{\mathrm{m}}\right)$ can (in corroboration with other methods, like circular dichroism or viscometry or NMR) be related to the various binding modes [39]. For example, if pyrene compounds intercalate into the ds-DNA, $\Delta \mathrm{T}_{\mathrm{m}}>2-5{ }^{\circ} \mathrm{C}$ can be expected, whereas the binding of pyrenes within the polynucleotide groove should have a negligible stabilizing effect for ds-helix [30].

The addition of referent open form of DAE- $\mathrm{NH}_{2}$ to any ds-DNA/RNA did not have any impact on the thermal stability of studied polynucleotides, as well as the addition of DAE-NH-Py to ct-DNA. However, the addition of DAE-NH-Py at ratio $r=0.2-0.3$ to AURNA resulted in the appearance of a second transition at a significantly higher temperature (Figure 6, Table 2). Intriguingly, the first transition at about $52{ }^{\circ} \mathrm{C}$, characteristic for a free AU-RNA, remained and attempt to completely saturate AU-RNA by adding more DAE$\mathrm{NH}-\mathrm{Py}$ caused precipitation-like changes. Thus, it seems that at the given ratio $\mathrm{r}=0.2-0.3$ 
part of available ds-RNA binding sites was strongly stabilized by DAE-NH-Py, while a simultaneously large portion of RNA remains free of a small molecule. Taking into account the given ratios $(r=0.2-0.3)$, it seems that DAE-NH-Py aggregates within RNA major groove into dimers. That would also agree with the lack of stabilization of ct-DNA since both DNA grooves lack depth and hydrophobicity of RNA major groove (Supplementary Materials Table S1).

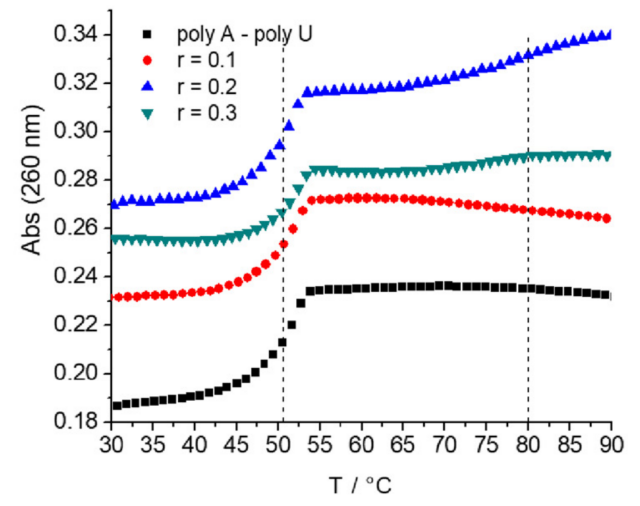

(a)

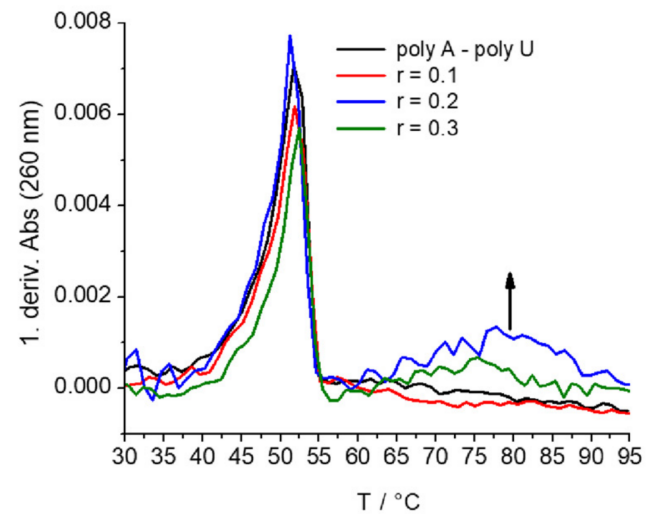

(b)

Figure 6. (a) Thermal denaturation of poly A-poly $U\left(c=2.0 \times 10^{-5} \mathrm{M}\right)$, upon addition $\mathrm{r}=0.1$, $\mathrm{r}=0.2, \mathrm{r}=0.3$, ([compound/[polynucleotide]) of DAE-NH-Py (open form) at $\mathrm{pH} 7.0$ (buffer sodium cacodylate, $I=0.05 \mathrm{M}) / 0.5 \% \mathrm{DMSO},(\mathbf{b})$ The 1 . derivative of absorbance on temperature.

Table 2. ${ }^{\mathrm{a}} \Delta \mathrm{T}_{\mathrm{m}}$-Values $\left({ }^{\circ} \mathrm{C}\right)$ for different ratios ${ }^{\mathrm{b}} \mathrm{r}$ of DAE-NH $\mathrm{N}_{2}$ and DAE-NH-Py added to the polynucleotide.

\begin{tabular}{cccc}
\hline Compound & ${ }^{\mathbf{b}} \mathbf{r}$ & ct-DNA & poly A-poly U \\
\hline DAE-NH $_{2}$ (open form) & 0.3 & -1.0 & -0.7 \\
\hline & 0.1 & & 0.0 \\
DAE-NH-Py (open form) & 0.2 & -0.7 & $0.0 / 26.1$ \\
& 0.3 & -1.9 & $0 / 23.4$ \\
\hline DAE-NH-Py (closed form) & 0.3 & 0.3 \\
\hline
\end{tabular}

a $\Delta \mathrm{T}_{\mathrm{m}}$-Value error $\pm 0.5^{\circ} \mathrm{C} ;{ }^{\mathrm{b}} \mathrm{r}=$ [compound]/[polynucleotide].

The addition of a "closed" DAE-NH-Py form to both, ds-DNA or ds-RNA did not yield any thermal stabilization of polynucleotides (Table 2). Obviously, photo-cyclisation of DAE-NH-Py prevented the formation of assumed aggregate inside ds-RNA major groove, likely due to intensive stacking of pyrene(s) to cyclic DAE (as discussed at the end of Section 2.3.1).

\subsubsection{Circular Dichroism (CD) Experiments}

Close analogue of $\mathrm{DAE}^{-\mathrm{NH}_{2}}$ [13] in the open form was in equilibrium between two dynamic helices of opposite sign, thus having no distinctive CD spectrum. Photochemical ring-closure locks the conformation of the switch in the fixed chirality, however, still not showing a measurable intrinsic $C D$ spectrum due to the equimolar enantiomeric ratio [13].

We collected CD spectra of DAE-NH-Py in both, open and closed form (Figure 7), intriguingly closed form showing weak negative CD band at 300-350 nm range, characteristic for pyrene absorption. Since pyrenes, as well as their aliphatic linkers, are not chiral, observed weak CD band suggests that at least one pyrene is in the interaction with DAE core, most likely by stacking interactions (see comments to Figures 2 and 3), which would result in the induced chirality. 


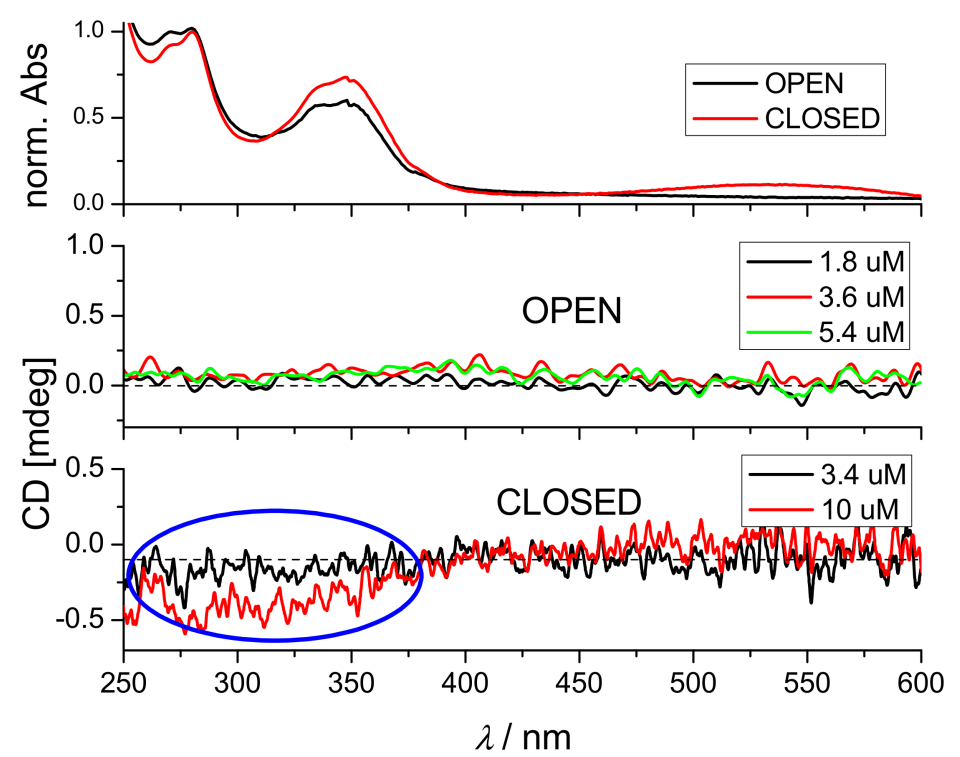

Figure 7. CD spectra of DAE-NH-Py $\left(c=1.8-10 \times 10^{-6} \mathrm{M}\right)$ in an open and closed form, overlaid with corresponding UV/Vis spectra (normalized). Done at $\mathrm{pH} 7.0$, buffer sodium cacodylate, $I=0.05 \mathrm{M}$.

The addition of DAE-NH-Py to ds-DNA caused only a minor decrease of CD bands at $245 \mathrm{~nm}$ and $275 \mathrm{~nm}$ (Figure 8a, attributed to the minor unwinding of ds-DNA), which reached saturation at ratio $\mathrm{r}=0.2$ (Figure $8 \mathrm{~b}$ ). No induced $\mathrm{CD}$ (ICD) bands $>300 \mathrm{~nm}$ were observed, thus pointing out that pyrenes are not uniformly oriented in respect to DNA chiral axis [40].

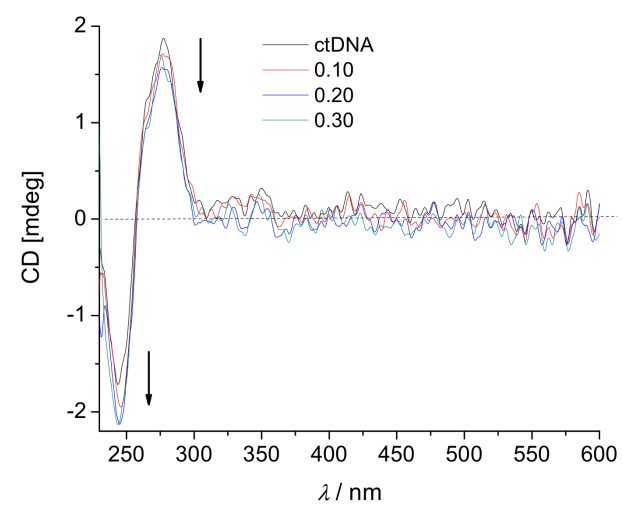

(a)

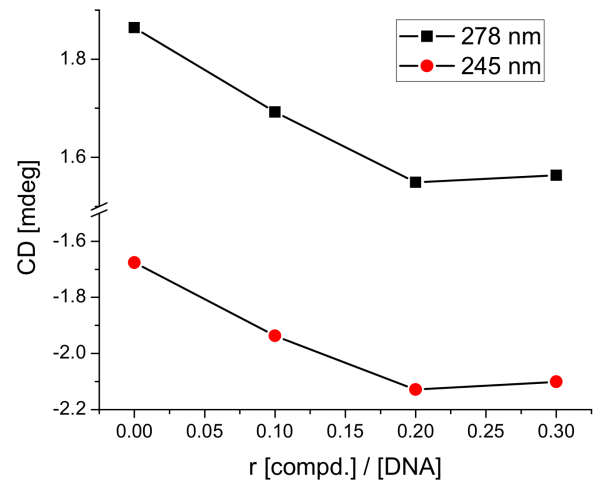

(b)

Figure 8. (a) CD titration of ct-DNA $\left(c=2 \times 10^{-5} \mathrm{M}\right)$ with DAE-NH-Py closed at molar ratios $\mathrm{r}=$ [compound]/[DNA]; (b) dependence of CD maxima at $245 \mathrm{~nm}$ and $278 \mathrm{~nm}$ on a ratio $\mathrm{r}$. Done at $\mathrm{pH} 7.0$, buffer sodium cacodylate, $I=0.05 \mathrm{M}$.

Differently, the addition of closed DAE-NH-Py to AU-RNA induced a very weak ICD band change at 300-350 nm (Figure 9, up), likely due to the ICD band of pyrene. Intriguingly, open DAE-NH-Py did not cause such change in the CD spectrum of AU-RNA (Figure 9, down).

Analogous experiments with open $\mathrm{DAE}-\mathrm{NH}_{2}$ did not change $\mathrm{CD}$ spectra of studied DNA/RNA (Supplementary Materials, Figure S22), whereas closed DAE- $\mathrm{NH}_{2}$ somewhat changed the $\mathrm{CD}$ spectrum of only poly A-poly $\mathrm{U}$ but no changes were observed for ct-DNA. These results are at variance to previously reported for close analogue DAEphenyl- $\mathrm{NH}_{2}$ [13], where binding to ds-DNAs resulted in weak but measurable ICD bands at $350 \mathrm{~nm}$ and $570 \mathrm{~nm}$, characterized as DAE-phenyl-core uniformly oriented in the respect of ds-DNA helical axis. Most likely extension of DAE with phenyl [13] yielded a longer 
aromatic system, which then uniformly positioned chromophore within DNA binding site, thus yielding ICD band(s).

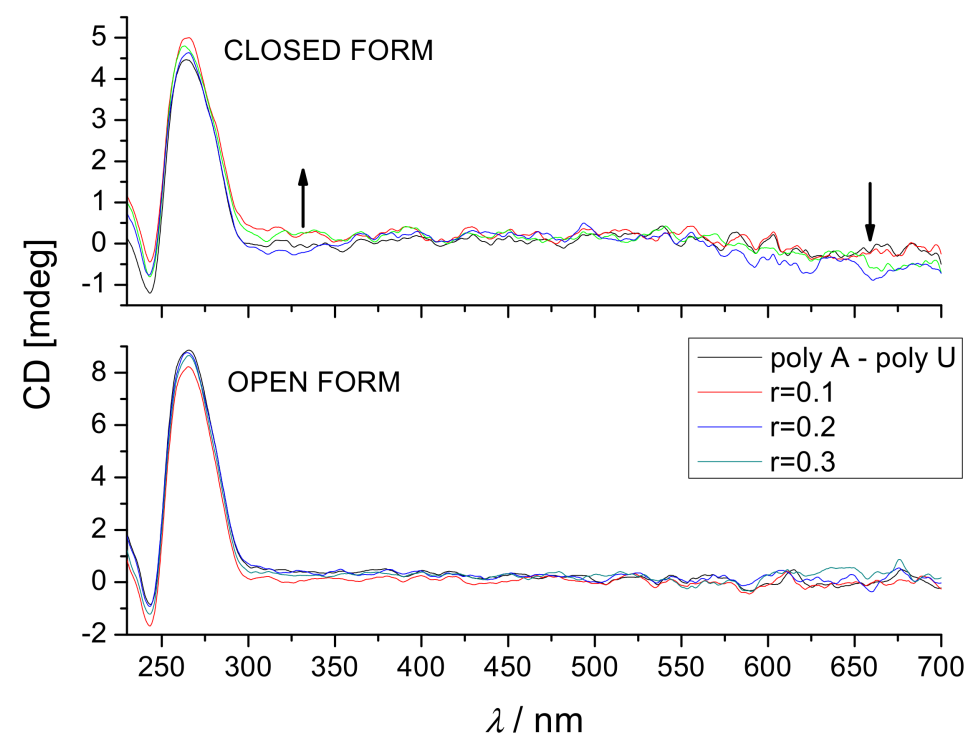

Figure 9. CD titration of poly A-poly $\mathrm{U}\left(c=2 \times 10^{-5} \mathrm{M}\right)$ with open and closed form of DAE-NH-Py at molar ratios $\mathrm{r}=$ [compound] $/[\mathrm{RNA}]$. Done at $\mathrm{pH} 7.0$, buffer sodium cacodylate, $I=0.05 \mathrm{M}$.

\subsubsection{Fluorimetric Titrations}

Pyrene analogue DAE-NH-Py is characterized by fluorescence emission sensitive to the microenvironment, as demonstrated by open DAE-NH-Py emitting strong emission at $480 \mathrm{~nm}$, while closed DAE-NH-Py emits 20-fold weaker emission at about $400 \mathrm{~nm}$ (Figure 3). Based on that we expected that open and closed DAE-NH-Py will interact quite differently with ds-DNA or ds-RNA and their emission will change accordingly.

Addition of the most ds-DNA/RNA to open DAE-NH-Py resulted in quenching of fluorescence for about 10-25\% (Figure 10), the only exception being GC-DNA (Supplementary Materials, Figure S26), which did not influence open DAE-NH-Py emission. Structural specificity of GC-DNA in respect to other used ds-DNA/RNAs is sterically blocked minor groove by protruding amino groups of guanine [41], which obviously hampered deep insertion of pyrenes into the hydrophobic groove, leaving them exposed to the aqueous environment and therefore not changing their fluorescence.

The addition of any ds-DNA/RNA did not change the fluorescence of closed DAENH-Py (Supplementary Materials, Figure S27). The closed form seems to be sterically locked by intramolecular stacking interactions of pyrene(s) and cyclic DAE, thus, forming a highly rigid, aryl-stacked system, which does not fit into any DNA or RNA groove.

Processing of fluorimetric titration data (Figure 10) by means of the Scatchard equation [42] allowed the determination of binding constants (Table 3). The binding affinities are similar, the almost order of magnitude stronger binding to AT-DNA in respect to ct-DNA probably due to the $48 \%$ of GC-basepairs in ct-DNA, in which minor groove binding is hampered by protruding amino groups of guanine [41].

Table 3. Binding constants and emission changes $\left({ }^{\mathrm{a}} \log K s\left(\mathrm{M}^{-1}\right){ }^{\mathrm{b}} \Delta \operatorname{Int}(\%)\right)$ of open DAE-NH-Py complexes with ds-polynucleotides calculated by processing fluorimetric titrations.

\begin{tabular}{cccc}
\hline ct-DNA & AT-DNA & GC-DNA & AU-RNA \\
\hline $5.6 / 26$ & $6.3 / 11$ & c & $6.1 / 22$ \\
\hline
\end{tabular}

a Processing of titration data by means of Scatchard Equation [42] gave values of ratio n[bound dye] $/$ [polynucleotide] $=0.1-0.2$, for easier comparison all $\log K s$ values were re-calculated for fixed $n=0.2$. Correlation coefficients were $>0.99$ for all calculated $\log K_{s} \cdot{ }^{b} \Delta \operatorname{Int}=\left[\left(\operatorname{Int}(\mathrm{DAE}-\mathrm{NH}-\mathrm{Py})-\mathrm{Int}_{\text {complex }}\right) /\right.$ Int $(\mathrm{DAE}-\mathrm{NH}-$ $\mathrm{Py})] \times 100 ;{ }^{\mathrm{c}}$ Too small changes for accurate processing by Scatchard eq. 


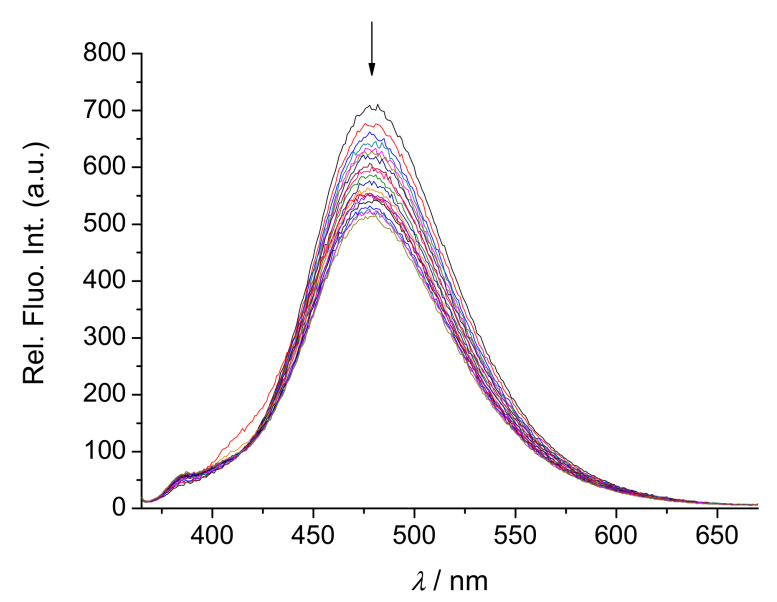

(a)

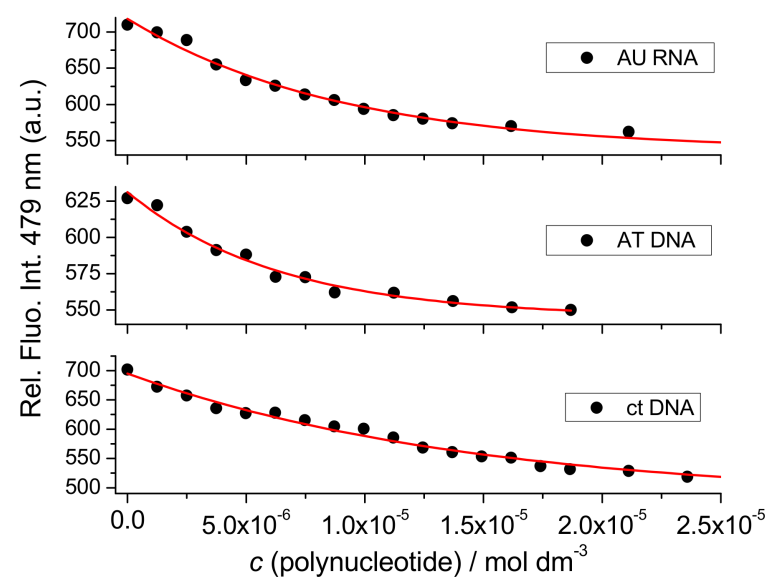

(b)

Figure 10. (a) Changes in fluorescence spectrum of DAE-NH-Py open $\left(c=1.0 \times 10^{-6} \mathrm{M}\right)$ upon titration with ct-DNA; (b) Dependence of emission intensity at $\lambda_{\max }=479 \mathrm{~nm}$ on c(polynucleotide), data fitted to Scatchard Equation [42] (-). Done at $\mathrm{pH}=7.0$, buffer sodium cacodylate, $I=0.05 \mathrm{M}$, $0.04 \%$ DMSO.

\subsection{Interactions with $B S A$}

The addition of BSA to DAE-NH-Py resulted in different changes of pyrene emission, strongly dependent on a DAE state (open vs. closed). Namely, emission of pyrene excimer $\left(\lambda_{\max }=480 \mathrm{~nm}\right)$ DAE-NH-Py open was quenched, reaching the end of a titration at ratio r[dye]/[BSA] 3:1 (Figure 11); at variance to DAE-NH-Py closed, which showed emission increase $\left(\lambda_{\max }=400 \mathrm{~nm}\right.$, Figure 12) only at large excess of dye over BSA.

Since BSA has multiple binding sites for small molecules and thus, DAE-NH-Py can bind to protein in several different stoichiometries, titration data were processed by nonlinear regression analysis using the HypSpec2014 program [43], designed for multivariate analysis of complex systems.

Analysis of DAE-NH-Py open titration data gave the best fit for the formation of r[DAE-NH-Py open]/[BSA] = 3:1 complex (Figure 11b) with calculated cumulative binding constant $\log \beta_{3: 1}=19 \pm 0.7 \mathrm{M}^{-3}$, which agreed well with the distribution of spectroscopically active species (Figure 11c), approaching $>70 \%$ of complex formed. Statistically, at large excess of BSA over dye $\left(\mathrm{r}_{[\mathrm{dye}] /[\mathrm{BSA}]}<0.01\right), 2: 1$ and 1:1 complex stoichiometries should also be present; however, such high concentrations of BSA are not biologically relevant. We also tried to fit titration data to coexisting 2:1 and 3:1 dye/BSA complexes and got $\log \beta_{2: 1}=11 \pm 1.6 \mathrm{M}^{-2} ; \log \beta_{3: 1}=18 \pm 0.9 \mathrm{M}^{-3}$ with a very low percentage of 2:1 complex 
(thus, large error of $\log \beta_{2: 1}$ ), whereas model containing 1:1, 2:1 and 3:1 stoichiometry was not possible to fit to experimental data. Thus, at given titration conditions, a 3:1 stoichiometry complex is the dominant species.

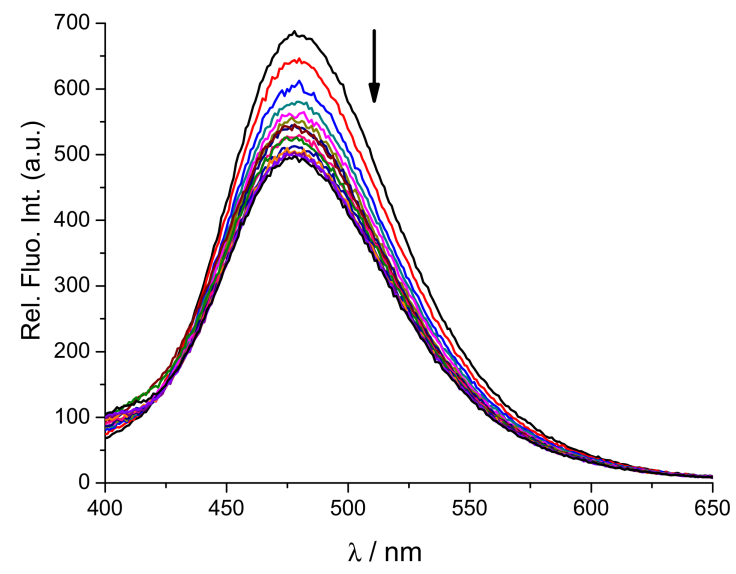

(a)

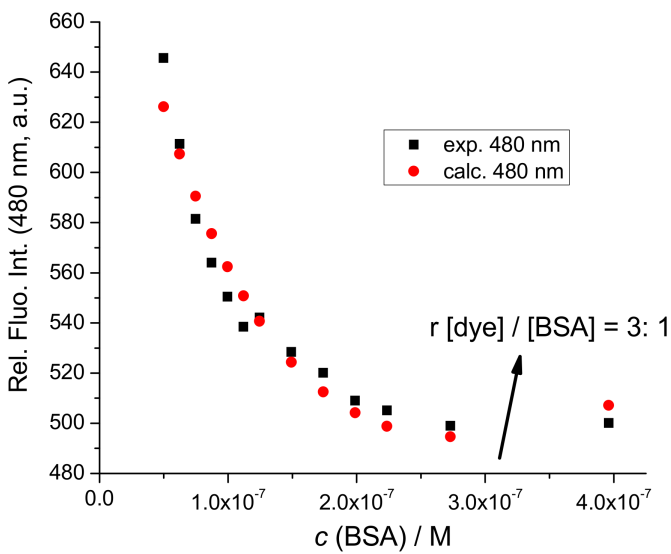

(b)

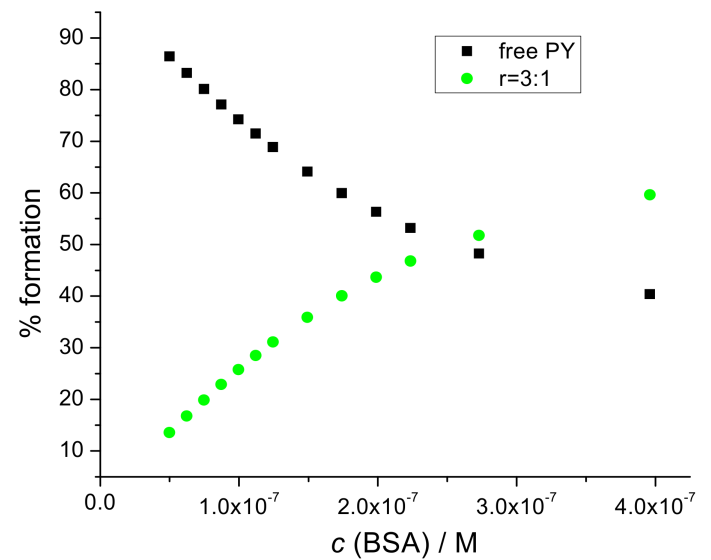

(c)

Figure 11. (a) Fluorimetric titration of DAE-NH-Py open $\left(c=1 \times 10^{-6} \mathrm{M} ; \lambda_{\text {exc }}=342 \mathrm{~nm}\right)$ with BSA; (b) Dependence

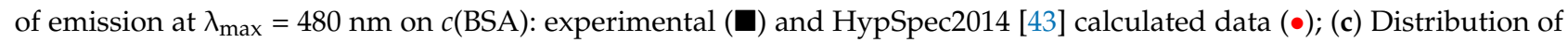
spectroscopically active species dependent on a $c$ (BSA) based on HypSpec2014 processing [43], free DAE-NH-Py open (ם); 3:1 complex $(\bullet)$. Done at $\mathrm{pH} 7.0$, buffer sodium cacodylate, $I=0.05 \mathrm{M}$.

The structural meaning of [DAE-NH-Py open]/[BSA] 3:1 complex implies that dye is bound to the three different binding sites on BSA with similar affinity $\left(\beta_{3: 1}=\mathrm{K}_{\mathrm{s} 1} \times \mathrm{K}_{\mathrm{s} 2} \times \mathrm{K}_{\mathrm{s} 3}\right)$. A detailed determination which binding sites are targeted would require an elaborate set of competition experiments with particular small molecules known to specifically target some BSA binding site (see Figure 1 in ref. [34]), which is out of the scope of this work.

Oppositely to DAE-NH-Py open, analysis of DAE-NH-Py closed titration data gave the best fit (Figure 12b) for the formation of r[DAE-NH-Py closed] $/$ [BSA] $=1: 1$ complex with binding constant $\log \mathrm{K}_{\mathrm{s} 1: 1}=6.0 \pm 0.5 \mathrm{M}^{-1}$, which agreed well with the distribution of spectroscopically active species (Figure 11c), approaching $>70 \%$ of complex formed. Attempts to fit experimental data to any higher stoichiometry (2:1 or 3:1) failed, thus, clearly stressing that only one type of complex is formed.

Such difference in binding stoichiometries and affinities between the open and closed form of DAE-NH-Py can be attributed to the larger flexibility of DAE in open form, which, therefore, easily accommodates within several different binding sites on BSA. The closed form seems to be sterically locked by intramolecular stacking interactions of pyrene(s) and 
cyclic DAE, thus forming a highly rigid, aryl-stacked system, which binds efficiently in only one BSA binding site, hence giving 1:1 stoichiometry. According to the literature, most BSA/HSA ligands are of low molecular weight $(\mathrm{Mw}<500)$, except bilirubin and hemin $(\mathrm{Mw}>700)$, which bind to the IB:FA1 position of HSA. This binding site is characterized by a deep hydrophobic cleft [34,44], which would by size agree with a stacked DAE-NH-Py closed system.

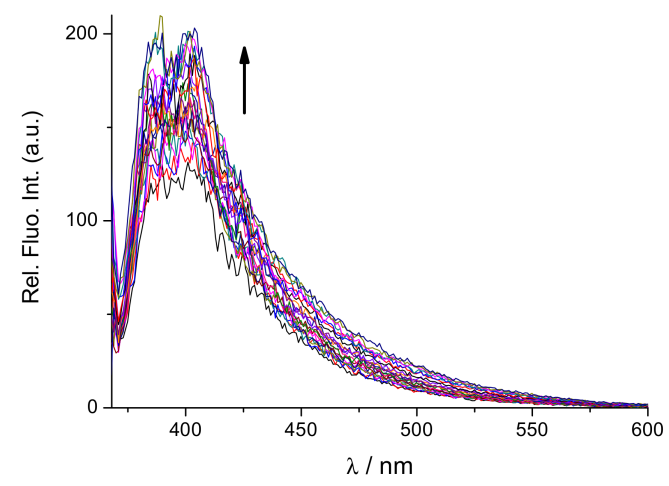

(a)

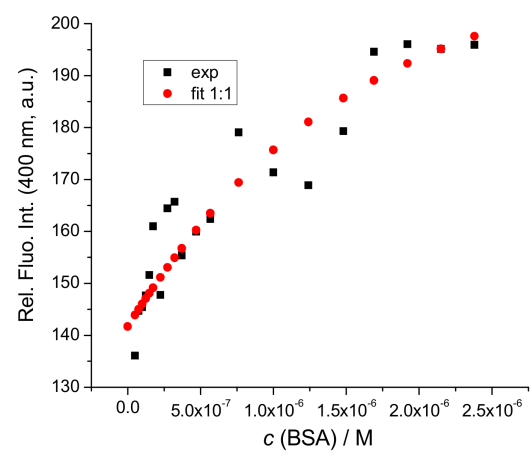

(b)

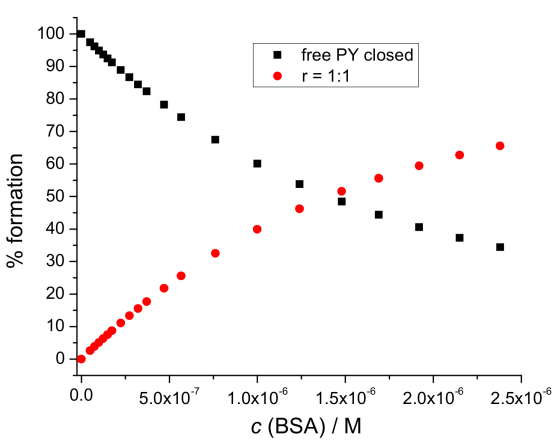

(c)

Figure 12. (a) Fluorimetric titration of DAE-NH-Py closed $\left(c=1 \times 10^{-6} \mathrm{M} ; \lambda_{\text {exc }}=342 \mathrm{~nm}\right)$ with BSA;

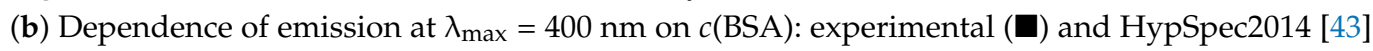
calculated data $(\bullet)$; (c) Distribution of spectroscopically active species dependent on a $c$ (BSA) based on HypSpec2014 processing [43], free DAE-NH-Py closed (ם); 1:1 complex (•). Done at pH 7.0, buffer sodium cacodylate, $I=0.05 \mathrm{M}$.

\subsection{Biological Experiments}

It has been reported that many pyrene derivatives exhibit intriguing biorelevant interactions [2], and even in some cases show intracellular organelle recognition (e.g., mitochondrial) [29]. Additionally, under UV irradiation some pyrenes produce singlet oxygen-related species, thus, having photodynamic therapy (PDT) effect.

For that reason, we preliminarily screened cytotoxic activity of DAE-NH-Py and referent DAE- $\mathrm{NH}_{2}$ by the MTT assay (for $72 \mathrm{~h}$ ) against human lung carcinoma (A549) cell line (Figure 13). Tested cells were in two parallel experiments either kept in dark or irradiated by UV-A light in the photoreactor (Luzchem, LZC-ICH2), equipped with eight overhead-mounted LZC-UVA lamps (in total $64 \mathrm{~W}, 315-400 \mathrm{~nm}$ ), latter irradiation performed for $30 \mathrm{~min}$ on the 1st, 2nd and 3rd day. Results showed that both compounds are non-toxic even at the highest concentration if not exposed to light, referent $\mathrm{DAE}-\mathrm{NH}_{2}$ being also non-toxic even at prolonged light irradiation (Figure 13a). However, DAE-NH-Py upon $30 \mathrm{~min}$ irradiation exhibited concentration-dependent cytotoxic activity (Figure 13b, UV $30 \mathrm{~min}$ ), measurable as low as at $1 \mu \mathrm{M}$. 


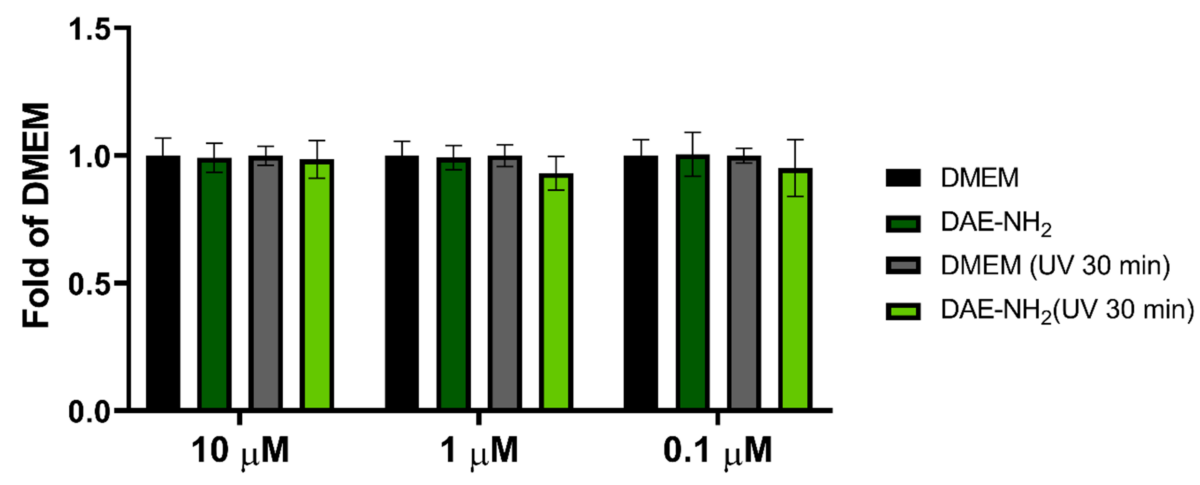

(a)

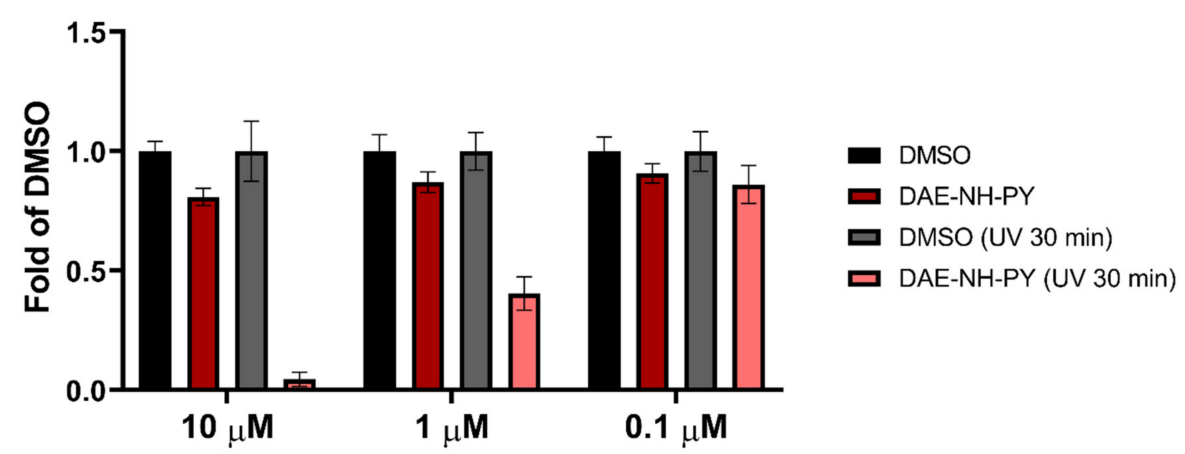

(b)

Figure 13. Cell survival of A549 cells treated with DAE-NH 2 (a) or DAE-NH-Py (b), with or without UV-A light irradiation (30 min each of three days of cell incubation). Control samples are cells treated with DMSO for DAE-NH-Py, or DMEM for DAE-NH 2 . Representative data of three independent experiments which yielded similar results are shown. Data are presented as relative to the control samples $\pm \mathrm{SD}$, made in three replicates.

Since DAE-NH-Py showed a distinct cytotoxic effect when irradiated, we took advantage of its fluorescence to study its cellular uptake and intracellular distribution in A549 cells by confocal microscopy. DAE-NH-Py at $10 \mu \mathrm{M}$ efficiently entered live cells within 90 min incubation at $37^{\circ} \mathrm{C}, 5 \% \mathrm{CO}_{2}$ and non-selectively distributed within the cytoplasm (Figure 14).

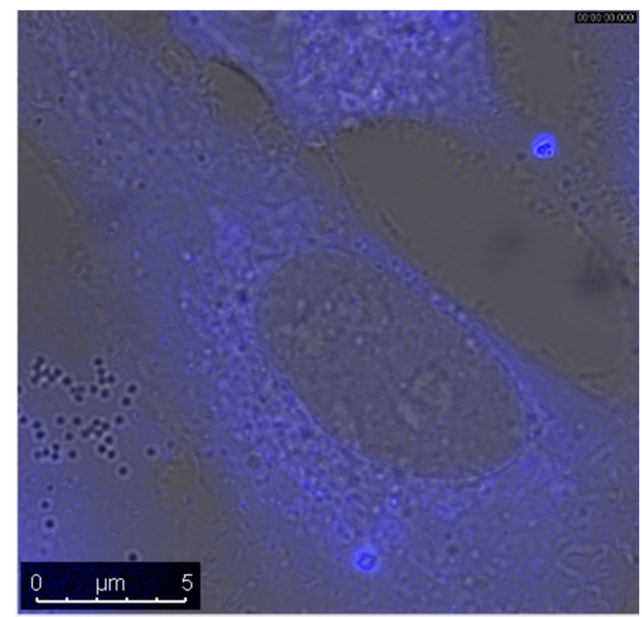

Figure 14. Uptake and localization of DAE-NH-Py $(c=10 \mu \mathrm{M})$ in live A549 cells. Cells were treated with DAE-NH-Py for $90 \mathrm{~min}$ at $37^{\circ} \mathrm{C}$, the surplus of the dye washed with DMEM and subsequently observed by confocal microscopy, $\lambda_{\mathrm{exc}}=405 \mathrm{~nm}, \lambda_{\mathrm{em}}=420-550 \mathrm{~nm}$. Under the same instrument conditions, no auto-fluorescence of non-treated cells was detected. 


\section{Conclusions}

Here, we described the synthesis of three novel diarylethene (DAE) photoswitches and fully characterized their spectroscopic and photochemical properties in $\mathrm{MeOH}$ and aqueous solution. All derivatives showed excellent photo-switching property of central DAE core in $\mathrm{MeOH}$, comparable to previously published close analogues. [13] Intriguingly, photoinduced cyclisation kinetics of DAE showed to be concentration-dependent, for $c$ (DAE-dye) $>\mathrm{mM}$ significantly slowing down, which was attributed to aromatic stacking interactions of DAE at such high concentrations: property not previously reported for DAE analogues. Moreover, in aqueous solution only $-\mathrm{NH}_{2}$ and $\mathrm{NH}$-Boc derivatives showed fast and efficient DAE photo-switching between open and closed form comparable to $\mathrm{MeOH}$ solution, whereas DAE of bis-pyrene derivative (DAE-NH-Py) was readily photo-chemically closed but could not be reversely photo-chemically opened. Intriguingly, open DAE-NH-Py was characterized by strong pyrene-aggregate emission at $480 \mathrm{~nm}$, which was upon photocyclisation completely quenched to give rise to weak pyrene emission at $400 \mathrm{~nm}$, suggesting stacking of pyrene to another aryl (DAE). Such photochemical irreversibility in water was attributed to strong intramolecular aromatic stacking interactions of pyrenes with cyclic (closed) DAE unit, which prevented the photo-induced opening of DAE. Such solventdependent impact on DAE photochemistry, actually controlled by intramolecular aromatic stacking interactions, was to the best of our knowledge not reported until now and could be used in multi-dynamic control of the photo-switching process.

Further, to explore the bio-applicability of novel compounds, we studied their interactions with the most common biomacromolecular targets for small molecules: ds-DNA, ds-RNA and biologically most abundant protein BSA. Referent DAE- $\mathrm{NH}_{2}$ did not interact significantly with any of the studied DNA/RNA. Only open DAE-NH-Py showed measurable interactions with ds-DNA and ds-RNA with affinity in the micromolar range and fluorimetric selectivity for only $\mathrm{AT}(\mathrm{U})$ polynucleotides, attributed to deep insertion in respective grooves. For GC-DNA open DAE-NH-Py fluorimetric change was negligible due to blocked minor groove. Oppositely, closed DAE-NH-Py analogue did not interact with DNA/RNA, likely due to intramolecularly stacked conformation, too large for insertion into DNA/RNA groove. Very intriguingly, both, open and closed DAE-NH-Py interacted with BSA but in very different modes. More flexible open DAE-NH-Py was bound at three different BSA binding sites with very high cumulative affinity, while self-stacked closed DAE-NH-Py binds to only one.

Next, for the fluorescent DAE-NH-Py efficient cellular uptake in human tumor cells was demonstrated, whereby dye was localized in the cytoplasm, nonetheless we determined that studied compounds are non-toxic to human cell lines. However, when DAE-NH-Py treated cells were exposed for only $30 \mathrm{~min}$ to UV-light $(315-400 \mathrm{~nm})$, a strong cytotoxic effect was observed, attributed to pyrene ability to produce singlet oxygen-related species under irradiation.

Thus, particularly DAE-NH-Py, combining fluorescent emission with photo-induced bioactivity, can be considered as a promising lead compound for the development of photo-induced theranostic agents [5,28], particularly in PDT therapy under two-photon absorption (PTA) [29] conditions.

\section{Materials and Methods}

\subsection{General}

Solvents were distilled from appropriate drying agents shortly before use. TLC was carried out on TLC Silica gel 60 F254 Plastic sheets and preparative thin layer (2 mm) chromatography was done on Merck 60 F254 plates (Merck KGaA, Darmstadt, Germany). NMR spectra were recorded on AV600 and AV300 MHz spectrometers (Bruker BioSpin $\mathrm{GmbH}$, Rheinstetten, Germany), operating at 600.13 or $300.13 \mathrm{MHz}$ for ${ }^{1} \mathrm{H}$ nuclei and at $150.92 \mathrm{MHz}$ or $75.46 \mathrm{MHz}$ for ${ }^{13} \mathrm{C}$, using DMSO- $d_{6}\left(\delta_{\mathrm{H}}: 2.50 \mathrm{ppm}, \delta_{\mathrm{C}}: 39.52 \mathrm{ppm}\right)$ or $\mathrm{CDCl}_{3}$ $\left(\delta_{\mathrm{H}}: 7.26 \mathrm{ppm}, \delta_{\mathrm{C}}: 77.16 \mathrm{ppm}\right)$ as the internal standard. Mass spectrometry was performed on an Agilent 6410 Triple Quad mass spectrometer (Agilent Technologies, Santa Clara, 
CA, USA). High-resolution mass spectra (HRMS) were obtained using a Q-TOF2 hybrid quadrupole time-of-flight mass spectrometer (Micromass, Cary, NC, USA).

\subsection{Synthesis}

Compound S (200.0 mg, $0.57 \mathrm{mmol})$ was dissolved in dichloromethane in the threenecked flask $(8.0 \mathrm{~mL})$ under an argon atmosphere. The solution was cooled in an ice bath and N-methylmorpholine ( $127.0 \mu \mathrm{L}, 1.16 \mathrm{mmol})$ and 2-chloro-4,6-dimethoxy-1,3,5-triazine (200.0 mg, $1.14 \mathrm{mmol}$ ) were added.

The reaction mixture was stirred for two hours in an ice bath, then the second portion of $\mathrm{N}$-methylmorpholine $(127.0 \mu \mathrm{L}, 1.16 \mathrm{mmol})$ and Boc-ethylenediamine $7(68.0 \mu \mathrm{L}$, $1.15 \mathrm{mmol}$ ) was added. After stirring for an additional $1 \mathrm{~h}$ in an ice bath, the reaction mixture was allowed to warm to room temperature overnight. The next day it was transferred to an extraction funnel with dichloromethane $(12.0 \mathrm{~mL})$ and washed twice with $1 \mathrm{M} \mathrm{HCl}(13.0 \mathrm{~mL})$, brine $(31.0 \mathrm{~mL})$, sodium bicarbonate $(31.0 \mathrm{~mL})$ and distilled water $(41.0 \mathrm{~mL})$. The organic layer was then dried over anhydrous $\mathrm{Na}_{2} \mathrm{SO}_{4}$. After evaporation of the solvent, the desired product DAE-NH-Boc (Figure 15) was isolated by preparative thin-layer chromatography in a solvent system of 9:1 dichloromethane-methanol (clear oil, $49.0 \mathrm{mg}, 14 \%)$.

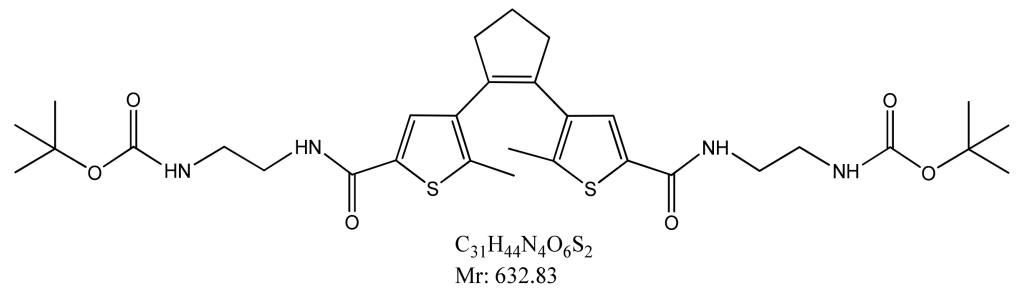

Figure 15. di-tert-butyl(((4,4'-(cyclopent-1-ene-1,2-diyl)bis(5-methylthiophene-4,2-diyl-2-carbonyl))bis (azanediyl))bis(ethane-2,1-diyl))dicarbamate (DAE-NH-Boc).

${ }^{1} \mathrm{H}$ NMR (300 MHz, CDCl $) \delta 7.23$ (s, 2H, 2CH, DAE), 6.85 (br s, 2H, 2NH), 5.05 (br $\mathrm{s}, 2 \mathrm{H}, 2 \mathrm{NH}), 3.48\left(\mathrm{q}, J=10.6,5.0 \mathrm{~Hz}, 4 \mathrm{H}, 2 \mathrm{CH}_{2}\right), 3.35\left(\mathrm{q}, J=4.6 \mathrm{~Hz}, 4 \mathrm{H}, 2 \mathrm{CH}_{2}\right), 2.76(\mathrm{t}$, $\left.J=7.4 \mathrm{~Hz}, 4 \mathrm{H}, 2 \mathrm{CH}_{2}, \mathrm{DAE}\right), 2.10-1.98(\mathrm{~m}, J=14.7,7.5 \mathrm{~Hz}, 2 \mathrm{H}, \mathrm{DAE}), 1.89\left(\mathrm{~s}, 6 \mathrm{H}, 2 \mathrm{CH}_{3}\right.$, DAE), 1.43 (s, 18H, BOC) ppm. ${ }^{13} \mathrm{C}$ NMR $\left(75 \mathrm{MHz}, \mathrm{CDCl}_{3}, 25^{\circ} \mathrm{C}, \mathrm{TMS}\right) \delta 162.57$ (qC, CONHR), 157.55 (Qc, $\mathrm{CO}_{2} \mathrm{NH}$ ), 140.15 (Qc, DAE), 136.41 (Qc, DAE), 134.90 (Qc, DAE), 134.52 (Qc, DAE), $129.44(2 \mathrm{CH}, \mathrm{DAE}), 80.07$ (qC, BOC), $41.87\left(2 \mathrm{CH}_{2}\right), 40.20\left(2 \mathrm{CH}_{2}\right), 38.66$ $\left(\mathrm{CH}_{2}, \mathrm{DAE}\right), 28.52\left(6 \mathrm{CH}_{3}, \mathrm{BOC}\right), 23.06\left(2 \mathrm{CH}_{2}, \mathrm{DAE}\right), 14.80\left(2 \mathrm{CH}_{3}, \mathrm{DAE}\right) \mathrm{ppm}$. HRMS (MALDI-TOF/TOF)): calcd for $\mathrm{C}_{31} \mathrm{H}_{44} \mathrm{~N}_{4} \mathrm{O}_{6} \mathrm{~S}_{2} \mathrm{Na}^{+}$[M-Na] ${ }^{+}$: 655.2599; found: 655.3011.

In a round-bottomed flask, DAE-NH-Boc $(35.0 \mathrm{mg}, 0.06 \mathrm{mmol})$ was dissolved in dichloromethane $(4.0 \mathrm{~mL})$ after which the solution was cooled in an ice bath. Trifluoroacetic acid $(4.0 \mathrm{~mL}, 52.24 \mathrm{mmol})$ was then slowly added dropwise to the cooled reaction mixture with stirring over half an hour. This was followed by stirring at room temperature for about $2 \mathrm{~h}$ until the complete disappearance of the starting compound was carried out by thin-layer chromatography in a 9:1 dichloromethane-methanol system. Product $\mathrm{DAE}-\mathrm{NH}_{2}$ (Figure 16) was obtained as a white solid $(30.0 \mathrm{mg}, 100 \%)$.

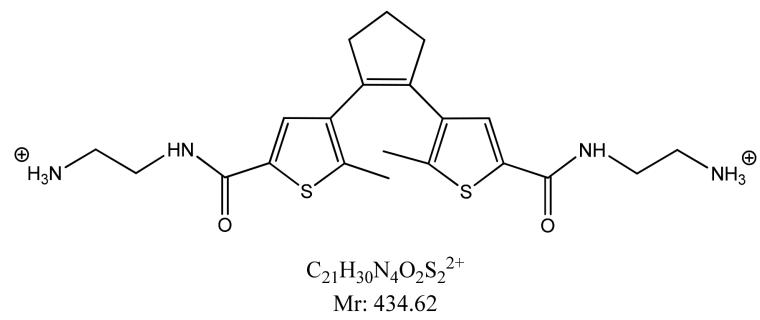

Figure 16. 2,2' -((4,4'-(cyclopent-1-ene-1,2-diyl)bis(5-methylthiophene-2,2'-carbonyl))bis(azanediyl)) diethanaminium $\left(\mathrm{DAE}^{-\mathrm{NH}_{2}}\right)$. 
${ }^{1} \mathrm{H}$ NMR (600 MHz, MeOD) $\delta 7.53(\mathrm{~s}, 2 \mathrm{H}, 2 \mathrm{CH}, \mathrm{DAE}), 3.63\left(\mathrm{t}, J=5.9 \mathrm{~Hz}, 4 \mathrm{H}, 2 \mathrm{CH}_{2}\right)$, $3.17\left(\mathrm{t}, J=5.9 \mathrm{~Hz}, 4 \mathrm{H}, 2 \mathrm{CH}_{2}\right), 2.87\left(\mathrm{t}, J=7.5 \mathrm{~Hz}, 4 \mathrm{H}, 2 \mathrm{CH}_{2}, \mathrm{DAE}\right), 2.18-2.12(\mathrm{~m}, 2 \mathrm{H}, \mathrm{DAE})$, $1.96\left(\mathrm{~s}, 6 \mathrm{H}, 2 \mathrm{CH}_{3}, \mathrm{DAE}\right) \mathrm{ppm} .{ }^{13} \mathrm{C}$ NMR $\left(151 \mathrm{MHz}, \mathrm{MeOD}, 25{ }^{\circ} \mathrm{C}, \mathrm{TMS}\right) \delta 165.24$ (Qc, CONHR), 142.23 (qC, DAE), 138.01 (Qc, DAE), 136.18 (Qc, DAE), 135.26 (Qc, DAE), 131.30 (2CH, DAE), $41.07\left(2 \mathrm{CH}_{2}\right), 39.64\left(2 \mathrm{CH}_{2}\right), 38.67\left(\mathrm{CH}_{2}, \mathrm{DAE}\right), 23.50\left(2 \mathrm{CH}_{2}, \mathrm{DAE}\right), 14.46\left(2 \mathrm{CH}_{3}\right.$, DAE) ppm. HRMS (MALDI-TOF/TOF)): calcd for C21H30N4O2S22 ${ }^{+}[\mathrm{M}-\mathrm{H}]^{+}:$: 433.1732; found: 433.1743 .

Compound S (54.4 mg, $0.16 \mathrm{mmol})$ was dissolved in dichloromethane $(2.0 \mathrm{~mL})$ under an argon atmosphere. The reaction mixture was cooled in an ice bath and $\mathrm{N}$ methylmorpholine $(34.8 \mu \mathrm{L}, 0.32 \mathrm{mmol})$ and 2-chloro-4,6-dimethoxy-1,3,5-triazine $(54.4 \mathrm{mg}$, $0.31 \mathrm{mmol}$ ) were added. The reaction mixture was stirred in an ice bath for $2 \mathrm{~h}$, then the second portion of $\mathrm{N}$-methylmorpholine $(34.8 \mu \mathrm{L}, 0.32 \mathrm{mmol})$ was added. Compound 10 ( $90.0 \mathrm{mg}, 0.31 \mathrm{mmol})$ was suspended in dichloromethane $(4.0 \mathrm{~mL})$ with the addition of dimethylformamide $(300.0 \mu \mathrm{L})$ followed by gradual dropwise addition to the reaction mixture. The reaction mixture was continued to stir at room temperature for $48 \mathrm{~h}$, after which it was transferred to an extraction funnel with dichloromethane $(3.3 \mathrm{~mL})$. It was washed twice with $1 \mathrm{M} \mathrm{HCl}(5.0 \mathrm{~mL})$, brine $(5.0 \mathrm{~mL})$, sodium bicarbonate $(7.0 \mathrm{~mL})$ and distilled water $(15.0 \mathrm{~mL})$. The organic layer was dried over anhydrous $\mathrm{Na}_{2} \mathrm{SO}_{4}$. Evaporation of the solvent gave a brown oil from which the desired product DAE-NH-Py (Figure 17) was isolated by preparative thin-layer chromatography in a 9:1 dichloromethane-methanol solvent system (white solid, $7.0 \mathrm{mg}, 5 \%$ ).

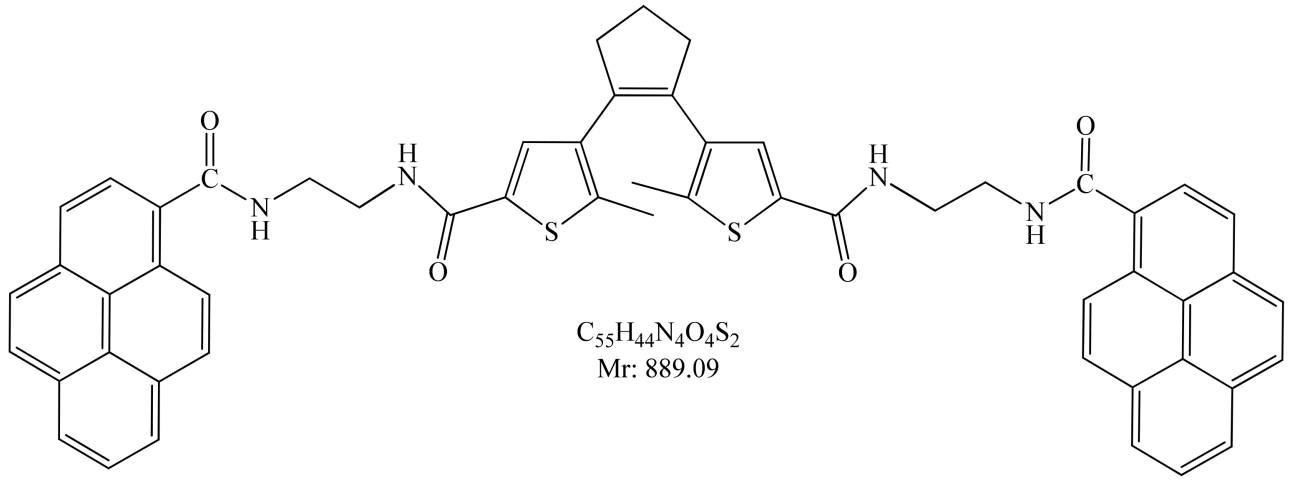

Figure 17. 4,4'-(cyclopent-1-ene-1,2-diyl)bis(5-methyl-N-(2-(pyrene-1-carboxamido)ethyl)thiophene2-carboxamide) (DAE-NH-Py).

${ }^{1} \mathrm{H}$ NMR (600 MHz, DMSO) $\delta 8.77(\mathrm{t}, 2 \mathrm{H}, 2 \mathrm{NH}), 8.54(\mathrm{t}, 2 \mathrm{H}, 2 \mathrm{NH}), 8.51(\mathrm{~d}, J=9.2 \mathrm{~Hz}$, 2H, Py), 8.33 (dd, $J=17.5,7.7 \mathrm{~Hz}, 6 \mathrm{H}, \mathrm{Py}), 8.27-8.10$ (m, 10H, Py), 7.59 (s, 2H, 2CH, DAE), $3.57\left(\mathrm{q}, 4 \mathrm{H}, 2 \mathrm{CH}_{2}\right), 3.52\left(\mathrm{q}, 4 \mathrm{H}, 2 \mathrm{CH}_{2}\right), 2.78\left(\mathrm{t}, 4 \mathrm{H}, 2 \mathrm{CH}_{2}, \mathrm{DAE}\right), 2.06-1.99\left(\mathrm{~m}, 2 \mathrm{H}, \mathrm{CH}_{2}\right.$, DAE), $1.82\left(\mathrm{~s}, 6 \mathrm{H}, 2 \mathrm{CH}_{3}, \mathrm{DAE}\right) \mathrm{ppm} .{ }^{13} \mathrm{C}$ NMR $\left(75 \mathrm{MHz}\right.$, DMSO, $25{ }^{\circ} \mathrm{C}$, TMS) $\delta 169.11$ (CONHPy), 161.27 (CONHR), 138.86 (qC, DAE), 136.05 (qC, DAE), 135.81 (qC, DAE), 134.11 (qC, DAE), 131.92 (qC, Py), 131.60 (qC, Py), 130.73 (qC, Py), 130.19 (qC, Py), 128.92 (2CH, DAE), 128.30 (CH, Py), 128.00 (CH, Py), 127.80 (qC, Py), 127.23 (CH, Py), 126.60 (CH, Py), 125.81 (CH, Py), 125.57 (CH, Py), 125.34 (CH, Py), $124.83(\mathrm{CH}, \mathrm{Py}), 124.40(\mathrm{CH}, \mathrm{Py}), 123.78$ (qC, Py), 123.64 (qC, Py), $38.38\left(2 \mathrm{CH}_{2}, \mathrm{DAE}\right), 22.30\left(\mathrm{CH}_{2}, \mathrm{DAE}\right), 14.24\left(2 \mathrm{CH}_{3}, \mathrm{DAE}\right)$. HRMS (MALDI-TOF/TOF)): calcd for $\mathrm{C}_{55} \mathrm{H}_{44} \mathrm{~N}_{4} \mathrm{O}_{4} \mathrm{~S}_{2} \mathrm{Na}^{+}$[M-Na] $]^{+}$: 911.2702; found: 911.2674.

\subsection{Study of DNA/RNA Interactions}

All measurements were performed in aqueous buffer solution $(\mathrm{pH}=7.0, I=0.05 \mathrm{M}$, sodium cacodylate buffer). The UV-Vis spectra were recorded on a Varian Cary 100 Bio spectrometer, fluorescence spectra were recorded on a Varian Cary Eclipse fluorimeter and CD spectra were recorded on JASCO J815 spectropolarimeter at $25.0^{\circ} \mathrm{C}$ using appropriate quartz cuvettes (path length: $1 \mathrm{~cm}$ ). 
Polynucleotides were purchased as noted: poly dAdT—poly dAdT, poly dGdC—poly dGdC, poly A - poly U, (Sigma), calf thymus (ct)—DNA (Aldrich) and dissolved in sodium cacodylate buffer, $I=0.05 \mathrm{M}, \mathrm{pH}=7.0$. The ct-DNA was additionally sonicated and filtered through a $0.45 \mathrm{~mm}$ filter to obtain mostly short (ca. 100 base pairs) rod-like B-helical DNA fragments [45]. Polynucleotide concentration was determined spectroscopically [46] as the concentration of phosphates (corresponds to $c$ (nucleobase)).

Circular dichroism (CD) spectra were recorded on JASCO J-815 spectropolarimeter at room temperature using $1 \mathrm{~cm}$ path quartz cuvettes with a scanning speed of $200 \mathrm{~nm} / \mathrm{min}$ (an average of three accumulations). A buffer background was subtracted from each spectrum. CD experiments were performed by adding portions of the compound stock solution into the solution of the polynucleotide $\left(c=2 \times 10^{-5} \mathrm{M}\right)$.

Thermal melting curves for ds-DNA, ds-RNA and their complexes with studied compounds were determined as previously described [39] by following the absorption change at $260 \mathrm{~nm}$ as a function of temperature. The absorbance of the ligands was subtracted from every curve and the absorbance scale was normalized. $T_{m}$ values are the midpoints of the transition curves determined from the maximum of the first derivative and checked graphically by the tangent method. The $\Delta T_{m}$ values were calculated by subtracting $T_{m}$ of the free nucleic acid from $T_{m}$ of the complex. Every $\Delta T_{m}$ value here reported was the average of at least two measurements. The error in $\Delta T_{m}$ is $\pm 0.5^{\circ} \mathrm{C}$.

\subsection{Biology}

Cells: A549 (human lung carcinoma; ATCC CCL-185) were obtained from the ATCC Cell Biology Collection and were cultured according to the manufacturer's instructions. Cells were grown in Dulbecco Modified Eagle's Medium (DMEM, Sigma Aldrich, St. Louis, MO, USA) supplemented with $10 \%$ of fetal bovine serum (FBS, Sigma Aldrich, USA) at $37^{\circ} \mathrm{C}$ and $5 \% \mathrm{CO}_{2}$ in a humified atmosphere. Three biological replicas have been performed for all experiments.

Cytotoxicity assay; MTT: Studied compounds were dissolved in the appropriate volume of dimethyl sulfoxide solution (DMSO) under sterile conditions, to obtain the stock of $10 \mathrm{mM}$ solution and kept in the dark at $+4{ }^{\circ} \mathrm{C}$. Before each assay, a new fresh working solution has been prepared from the stock solution by diluting it with DMEM. Cells were seeded on 96 well plate in the concentration of $7 \times 10^{3}$ cells/well in $100 \mu \mathrm{L}$ of DMEM $(10 \% \mathrm{FBS})$ and left in the incubator overnight $\left(37^{\circ} \mathrm{C}, 5 \% \mathrm{CO}_{2}\right)$. The next day, $100 \mu \mathrm{L}$ of the working solution was added to the wells, thus the final concentration of tested compounds was obtained in the total volume of $200 \mu \mathrm{L} /$ well. All conditions were tested in quadruplicates. Cells treated with the same dilutions of DMSO represented control, while cells treated only with DMEM (10\% FBS) represented negative control. The plate was then incubated for the next $72 \mathrm{~h}\left(37^{\circ} \mathrm{C}, 5 \% \mathrm{CO}_{2}\right)$. After the incubation, the medium was removed and the $40 \mu \mathrm{L}$ of MTT solution was added to each well. The plate was incubated in the cell incubator for $3 \mathrm{~h}$, allowing the formazan crystals to form. After $3 \mathrm{~h}, 170 \mu \mathrm{L}$ of DMSO was added to each well and put on a shaker for $20 \mathrm{~min}$, allowing crystals to dissolve. The absorbance of the MTT-formazan product was measured with a microplate reader at $600 \mathrm{~nm}$. Absorbance value directly correlates with a cell survival.

For UV-A irradiation experiments cell cultures plates prepared as above were treated with studied compounds and irradiated in a Luzchem reactor with eight overhead-mounted LZC-UVA lamps (in total $64 \mathrm{~W}, 315-400 \mathrm{~nm}$, Dose $50.6 \mathrm{mw} \cdot \mathrm{m}^{-2}$ ), $\sim 18 \mathrm{~cm}$ lamp to cell-plate distance; at $90 \mathrm{~min}, 24 \mathrm{~h}$ and $48 \mathrm{~h}$ after treatment. Exposure to light was $30 \mathrm{~min}$ per day.

Live cell imaging: Live imaging of the cells treated with compounds was performed on the A549 cell line. Cells were seeded in Ibidi imaging cell chambers (Ibidi ${ }^{\circledR}$, Martinsried, Germany) in $500 \mu \mathrm{L}$ of the medium, with the concentration of $5 \times 10^{4}$ cells/well and left in the cell incubator for $48 \mathrm{~h}\left(37^{\circ} \mathrm{C}, 5 \% \mathrm{CO}_{2}\right)$. After two days, cells were treated with $10 \mu \mathrm{M}$ solution of a tested compound and left in the cell incubator for $90 \mathrm{~min}$ to allow the compound to enter the cells. After incubation, the medium was replaced with $500 \mu \mathrm{L}$ of 
fresh DMEM and cells were immediately observed by Leica SP8 X confocal microscope (Leica Microsystems, Wetzlar/Mannheim, Germany).

Supplementary Materials: The following are available online at https:/ /www.mdpi.com/article/10 .3390/ijms22094916/s1, additional data about synthetic procedures, structural properties of studied DNA and RNA; physico-chemical properties of studied compounds aqueous solutions, additional experimental data (fluorimetric and CD titrations, thermal denaturation experiments) of interactions with biomacromolecules.

Author Contributions: I.O. and M.M. share the first authorship for equal contributions; synthesis and characterization of new compounds I.O. and M.M.; study of interactions with biomacromolecules, I.O.; biological testing, I.P. (Isabela Pehar) and D.M.; Conceptualization, supervision, funding acquisition, writing of the manuscript, I.P. (Ivo Piantanida). All authors have read and agreed to the published version of the manuscript.

Funding: This research was funded by Croatian Science Foundation project IP-2018-01-5475.

Data Availability Statement: All data is contained within this manuscript and the Supplementary Materials file.

Acknowledgments: The authors are grateful to dr. sc. Nikola Basarić, Ruđer Bošković Institute, Zagreb, for the use of Luzchem reactor in the irradiation experiments.

Conflicts of Interest: The authors declare no conflict of interest.

\section{References}

1. Silverman, R.B. The Organic Chemistry of Drug Design and Drug Action; Elsevier Academic Press: New York, NY, USA, 2004.

2. Lakowicz, J.R.; Masters, B.R. Principles of Fluorescence Spectroscopy, 3rd ed.; Kluwer-Plenum: New York, NY, USA, 2008 ; p. 029901. [CrossRef]

3. Specht, E.A.; Braselmann, E.; Palmer, A.E. A critical and comparative review of fluorescent tools for live-cell imaging. Annu. Rev. Physiol. 2017, 79, 93-117. [CrossRef] [PubMed]

4. Zhao, X.; Yang, C.-X.; Chen, L.-G.; Yan, X.-P. Dual-stimuli responsive and reversibly activatable theranostic nanoprobe for precision tumor-targeting and fluorescence-guided photothermal therapy. Nat. Commun. 2017, 8, 14998. [CrossRef] [PubMed]

5. He, P.-P.; Li, X.-D.; Wang, L.; Wang, H. Bispyrene-Based Self-Assembled Nanomaterials: In Vivo Self-Assembly, Transformation, and Biomedical Effects. Acc. Chem. Res. 2019, 52, 367-378. [CrossRef] [PubMed]

6. Hernandez-Folgado, L.; Schmuck, C.; Tomić, S.; Piantanida, I. A novel pyrene-guanidiniocarbonyl-pyrrole cation efficiently differentiates between ds-DNA and ds-RNA by two independent, sensitive spectroscopic methods. Bioorg. Med. Chem. Lett. 2008, 18, 2977-2981. [CrossRef] [PubMed]

7. Hernandez-Folgado, L.; Bareticd, D.; Piantanida, I.; Marjanovicm, M.; Kralj, M.; Rehm, T.; Schmuck, C. GuanidiniocarbonylpyrroleAryl Derivatives: Structure Tuning for Spectrophotometric Recognition of Specific DNA and RNA Sequences and for Antiproliferative Activity. Chem. Eur. J. 2010, 16, 3036-3056. [CrossRef] [PubMed]

8. Wu, J.; Zou, Y.; Li, C.; Sicking, W.; Piantanida, I.; Yi, T.; Schmuck, C. A Molecular Peptide Beacon for the Ratiometric Sensing of Nucleic Acids. J. Am. Chem. Soc. 2012, 134, 1958-1961. [CrossRef]

9. Starcevic, K.; Karminski-Zamola, G.; Piantanida, I.; Zinic, M.; Suman, A.L.; Kralj, M. Photoinduced Switch of a DNA/RNA Inactive Molecule into a Classical Intercalator. J. Am. Chem. Soc. 2005, 127, 1074-1075. [CrossRef]

10. Berdnikova, D.V.; Gulakova, E.; Fedorova, O.; Ihmels, H. Photoinduced in situ generation of a DNA-binding benzothiazoloquinolinium derivative. Chem. Commun. 2012, 48, 4603-4605. [CrossRef]

11. Szymanski, W.; Beierle, J.M.; Kistemaker, H.A.V.; Velema, W.A.; Feringa, B.L. Reversible Photocontrol of Biological Systems by the Incorporation of Molecular Photoswitches. Chem. Rev. 2013, 113, 6114-6178. [CrossRef]

12. Velema, W.A.; Szymanski, W.; Feringa, B. Photopharmacology: Beyond Proof of Principle. J. Am. Chem. Soc. 2014, 136, $2178-2191$. [CrossRef]

13. Mammana, A.; Carroll, G.T.; Areephong, J.; Feringa, B.L. A Chiroptical Photoswitchable DNA Complex. J. Phys. Chem. B 2011, 115, 11581-11587. [CrossRef]

14. Deiana, M.; Pokladek, Z.; Olesiak-Banska, J.; Mlynarz, P.; Samoc, M.; Matczyszyn, K. Photochromic switching of the DNA helicity induced by azobenzene derivatives. Sci. Rep. 2016, 6, 28605. [CrossRef]

15. Muller, S.; Paulus, J.; Mattay, J.; Ihmels, H.; Dodero, V.I.; Sewald, N. Photocontrolled DNA minor groove interactions of imidazole/pyrrole polyamides. Beilstein J. Org. Chem. 2020, 16, 60-70. [CrossRef]

16. Kolsch, S.; Ihmels, H.; Mattay, J.; Sewald, N.; Patrick, B.O. Reversible photoswitching of the DNA-binding properties of styrylquinolizinium derivatives through photochromic [2+2] cycloaddition and cycloreversion. Beilstein J. Org. Chem. 2020, 16, 111-124. [CrossRef] 
17. Ihmels, H.; Mattay, J.; May, F.; Thomas, L. Photoswitchable DNA-binding properties of a photochromic spirooxazine derivative. Org. Biomol. Chem. 2013, 11, 5184. [CrossRef]

18. Berdnikova, D.V. Design, synthesis and investigation of water-soluble hemi-indigo photoswitches for bioapplications. Beilstein J. Org. Chem. 2019, 15, 2822-2829. [CrossRef]

19. Heinrich, B.; Bouazoune, K.; Wojcik, M.; Bakowsky, U.; Vazquez, O. ortho-Fluoroazobenzene derivatives as DNA intercalators for photocontrol of DNA and nucleosome binding by visible light. Org. Biomol. Chem. 2019, 17, 1827-1833. [CrossRef]

20. Bergen, A.; Rudiuk, S.; Morel, M.; le Saux, T.; Ihmels, H.; Baigl, D. Photodependent Melting of Unmodified DNA Using a Photosensitive Intercalator: A New and Generic Tool for Photoreversible Assembly of DNA Nanostructures at Constant Temperature. Nano Lett. 2016, 16, 773-780. [CrossRef]

21. Moratz, J.; Samanta, A.; Voskuhl, J.; Nalluri, S.K.M.; Ravoo, B.J. Light-Triggered Capture and Release of DNA and Proteins by Host-Guest Binding and Electrostatic Interaction. Chem. Eur. J. 2015, 21, 3271-3277. [CrossRef]

22. Dohno, C.; Uno, S.-N.; Sakai, S.; Oku, M.; Nakatani, K. The effect of linker length on binding affinity of a photoswitchable molecular glue for DNA. Bioorg. Med. Chem. 2009, 17, 2536-2543. [CrossRef]

23. Weston, C.E.; Richardson, R.D.; Haycock, P.R.; White, A.J.P.; Fuchter, M.J. Arylazopyrazoles: Azoheteroarene Photoswitches Offering Quantitative Isomerization and Long Thermal Half-Lives. J. Am. Chem. Soc. 2014, 136, 11878-11881. [CrossRef]

24. Schleper, A.L.; Bossi, M.L.; Belov, V.N.; Hell, S.W. Mono- and bithiophene-substituted diarylethene photoswitches with emissive open or closed forms. Beilstein J. Org. Chem. 2019, 15, 2344-2354. [CrossRef]

25. Nevskyi, O.; Sysoiev, D.; Dreier, J.; Stein, S.C.; Oppermann, A.; Lemken, F.; Janke, T.; Enderlein, J.; Testa, I.; Huhn, T.; et al. Fluorescent Diarylethene Photoswitches-A Universal Tool for Super-Resolution Microscopy in Nanostructured Materials. Small 2018, 14, 14. [CrossRef] [PubMed]

26. Kostenko, E.; Dobrikov, M.; Pyshnyi, D.; Petyuk, V.; Komarova, N.; Vlassov, V.; Zenkova, M. 5'-bis-pyrenylated oligonucleotides displaying excimer fluorescence provide sensitive probes of RNA sequence and structure. Nucleic Acids Res. 2001, 29, 3611-3620. [CrossRef]

27. Østergaard, M.E.; Hrdlicka, P.J. Pyrene-functionalized oligonucleotides and locked nucleic acids (LNAs): Tools for fundamental research, diagnostics, and nanotechnology. Chem. Soc. Rev. 2011, 40, 5771-5788. [CrossRef]

28. Mukherjee, S.; das Sarma, J.; Shunmugam, R. pH-Sensitive Nanoaggregates for Site-Specific Drug-Delivery as Well as Cancer Cell Imaging. ACS Omega 2016, 1, 755-764. [CrossRef] [PubMed]

29. Niko, Y.; Moritomo, H.; Sugihara, H.; Suzuki, Y.; Kawamata, J.; Konishi, G.-I. A novel pyrene-based two-photon active fluorescent dye efficiently excited and emitting in the 'tissue optical window (650-1100 nm)'. J. Mater. Chem. B 2015, 3, 184-190. [CrossRef] [PubMed]

30. Groger, K.; Baretić, D.; Piantanida, I.; Marjanović, M.; Kralj, M.; Grabar, M.; Tomić, S.; Schmuck, C. Guanidiniocarbonyl-pyrrolearyl conjugates as nucleic acid sensors: Switch of binding mode and spectroscopic responses by introducing additional binding sites into the linker. Org. Biomol. Chem. 2011, 9, 198-209. [CrossRef]

31. Smidlehner, T.; Badovinac, M.; Piantanida, I. Pyrene-cyanine conjugas multipurpose fluorescent probes for non-covalent recognition of ds-DNA, RNA and proteins. New J. Chem. 2018, 42, 6655-6663. [CrossRef]

32. Masaki, O.; Chuang, G. (Eds.) Albumin in Medicine. Pathological and Clinical Applications; Springer: Berlin/Heidelberg, Germany, 2016; ISBN 978-981-10-2116-9.

33. Peters, T., Jr. All About Albumin. Biochemistry, Genetics, and Medical Applications; Elsevier Inc.: Amsterdam, The Netherlands, 1995; ISBN 978-0-12-552110-9.

34. Varshney, A.; Sen, P.; Ahmad, E.; Rehan, M.; Subbarao, N.; Khan, R.H. Ligand binding strategies of human serum albumin: How can the cargo be utilized? Chirality 2010, 22, 77-87. [CrossRef] [PubMed]

35. Van Dijken, D.J.; Beierle, J.M.; Stuart, M.C.A.; Szymanski, W.; Browne, W.R.; Feringa, B.L. Autoamplification of molecular chirality through the induction of supramolecular chirality Angew. Chem. Int. Ed. 2014, 53, 5073-5077.

36. Kaminski, Z.J. 2-Chloro-4, 6-disubstituted-1, 3, 5-triazines a novel group of condensing reagents. Tetrahedron Lett. 1985, $26,2901$. [CrossRef]

37. Hartwig, S.; Nguyen, M.M.; Hecht, S. Exponential growth of functional poly(glutamic acid)dendrimers with variable stereochemistry. Polym. Chem. 2010, 1, 69-71. [CrossRef]

38. Logan, S.R. Does a Photochemical Reaction Have a Reaction Order? J. Chem. Educ. 1997, 74, 1303. [CrossRef]

39. Mergny, J.-L.; Lacroix, L. Analysis of Thermal Melting Curves. Oligonucleotides 2003, 13, 515-537. [CrossRef]

40. Smidlehner, T.; Piantanida, I.; Pescitelli, G. Polarization spectroscopy methods in the determination of interactions of small molecules with nucleic acids-tutorial. Beilstein J. Org. Chem. 2018, 14, 84-105. [CrossRef]

41. Egli, M.; Saenger, W. Principles of Nucleic Acid Structure; Springer: New York, NY, USA, 1983.

42. McGhee, J.D.; Hippel, P.H.V. Theoretical Aspects of DNA-Protein Interactions-Cooperative and Non-Cooperative Binding of Large Ligands to a One-Dimensional Homogeneous Lattice. J. Mol. Biol. 1974, 86, 469-489. [CrossRef]

43. Gans, P.; Sabatini, A.; Vacca, A. Investigation of equilibria in solution. Determination of equilibrium constants with the HYPERQUAD suite of programs. Talanta 1996, 43, 1739-1753. [CrossRef]

44. Zunszain, P.; Ghuman, J.; Curry, S. Human serum albumin complexed with 4Z,15E-bilirubin-IX-alpha. Hum. Serum Albumin Complexed 4Z,15E-Bilirubin-IX-Alpha 2008, 381, 394-406. [CrossRef] 
45. Chaires, J.B.; Dattagupta, N.; Crothers, D.M. Studies on interaction of anthracycline antibiotics and deoxyribonucleic acid: Equilibrium binding studies on the interaction of daunomycin with deoxyribonucleic acid. Biochemistry 1982, 21, 3933-3940. [CrossRef]

46. Tumir, L.M.; Piantanida, I.; Cindric, I.J.; Hrenar, T.; Meic, Z.; Zinic, M. New permanently charged phenanthridinium-nucleobase conjugates. Interactions with nucleotides and polynucleotides and recognition of ds-polyAH(+). J. Phys. Org. Chem. 2003, 16, 891-899. [CrossRef] 